\title{
Combining literature review, acoustic mapping and in situ observations: an overview of coralligenous assemblages in Liguria (NW Mediterranean Sea)
}

\author{
Almudena Cánovas Molina, Monica Montefalcone, Paolo Vassallo, Carla Morri, \\ Carlo Nike Bianchi, Giorgio Bavestrello
}

DiSTAV, Dipartimento di Scienze della Terra, dell'Ambiente e della Vita, Università di Genova, Corso Europa 26,

16132 Genova, Italy. E-mail: almucanovass@ gmail.com

\begin{abstract}
Summary: A review and update of the existing knowledge on the coralligenous assemblages of Liguria (NW Italy) was conducted as an essential step towards management measures for their conservation according to the EU Marine Strategy Framework Directive. By combining a literature review, acoustic mapping and in situ observations on a geographic information systems platform, we were able to assess the distribution and heterogeneity of coralligenous assemblages and the main pressures affecting them. The reliability of the literature was previously estimated using a dependability index. The coralligenous assemblages cover an area of 130.9 ha and range from 10 to $113 \mathrm{~m}$ depth. Twelve different biological facies (five of them not included in the EUNIS list) were identified and four main geomorphotypes (plungingcliffs, paleocliffs, rockfalls and shoals) were recognized. Incident light values influenced the distribution of four facies in Portofino promontory. Pressures were found on $33 \%$ of the coralligenous assemblages investigated, mainly due to fishing activities, mass mortality events, invasive species and occasional mucilaginous events. Our results showed a high spatial, geomorphological and biological heterogeneity of coralligenous assemblages in Liguria.
\end{abstract}

Keywords: mapping; literature review; heterogeneity; coralligenous assemblages; NW Mediterranean Sea.

Combinando revisión bibliográfica, mapas acústicos y observaciones in situ: sinopsis de las formaciones coralígenas en Liguria (NO del mar Mediterráneo)

Resumen: Una revisión y actualización del conocimiento existente sobre las formaciones coralígenas en Liguria (NO de Italia) ha sido implementado como paso esencial con vistas a las medidas de gestión para su conservación de acuerdo con la Directiva Marco sobre la Estrategia Marina. Combinando en plataforma SIG revisión bibliográfica, mapas acústicos y observaciones in situ hemos sido capaces de determinar la distribución de las formaciones coralígenas, su heterogeneidad y sus principales presiones. La fiabilidad de la bibliografía fue estimada a través del índice de confianza (DI). Las formaciones coralígenas cubren un área de 130.9 ha en un rango de profundidad que va desde los $10 \mathrm{~m}$ a los $113 \mathrm{~m}$. 12 facies biológicas diferentes ( 5 de ellas no incluidas en la lista EUNIS) fueron identificadas y 4 geomorfotipos principales (acantilado actual, paleoacantilado, cúmulo de rocas y bajos) fueron reconocidos. Los valores de luz incidente influenciaron la distribución de 4 facies en el promontorio de Portofino. Fueron encontradas presiones en el 33\% de las formaciones coralígenas investigadas, principalmente debidas a actividades de pesca, episodios de muerte masiva, especies invasoras y proliferación de algas mucilaginosas. Nuestros resultados mostraron una elevada heterogeneidad espacial, geomorfológica y biológica de las formaciones coralígenas en Liguria.

Palabras clave: mapeo; revisión bibliográfica; heterogeneidad; formaciones coralígenas; NO del mar Mediterraneo.

Citation/Como citar este artículo: Cánovas Molina A., Montefalcone M., Vassallo P., Morri C., Bianchi C.N., Bavestrello G. 2016. Combining literature review, acoustic mapping and in situ observations: an overview of coralligenous assemblages in Liguria (NW Mediterranean Sea). Sci. Mar. 80(1): 7-16. doi: http://dx.doi.org/10.3989/scimar.04235.23A

Editor: R. Sardà.

Received: March 2, 2015. Accepted: July 31, 2015. Published: December 11, 2015.

Copyright: () 2016 CSIC. This is an open-access article distributed under the Creative Commons Attribution-Non Commercial Lisence (by-nc) Spain 3.0. 


\section{INTRODUCTION}

Since Marion (1883) first coined the word "coralligène", coralligenous assemblages have been studied, classified and defined as hard substrata of biogenic origin that are mainly produced by the accumulation of calcareous encrusting algae, light being the main environmental factor affecting their development (Ballesteros 2006). Considered one of the most important and characteristic habitats of the Mediterranean Sea (Laborel 1961, 1987, Laubier 1966), coralligenous assemblages represent the climax biocenosis of the circalittoral zone (Pérès and Picard 1964), where endangered or commercially important fish species are known to live, feed or reproduce (Salomidi et al. 2012). Coralligenous communities are considered of high conservation interest because of their biogeographic uniqueness, their highly varied physical structure, their high species biodiversity, their highly diversified occurrence stratified throughout the different benthic marine zones and their slow growth (Ballesteros 2006, Agnesi et al. 2008, Salomidi et al. 2012).

Trawling has effects on seafloor that resemble those of forest clear-cutting (Watling and Norse 1998). It is the most destructive impact affecting the coralligenous habitat, but it is not the only one. Artisanal fishing, anchoring, diving, waste water discharges, aquaculture facilities, changes in land use, coastal infrastructure construction, urbanization, anomalous high water temperatures, proliferation of mucilage and invasive species are currently affecting the biodiversity and structure of coralligenous assemblages (Baldacconi and Corriero 2009, Ballesteros 2009, Linares et al. 2010).

Although the importance of coralligenous assemblages and the threats affecting them are commonly accepted within the scientific community and among managers, they were not listed among the priority habitats defined by the EU Habitat Directive (92/43/EEC), thus remaining without formal protection. Only one European law (Council Regulation (EC) No 1967/2006) prohibits destructive fishing over Mediterranean coralligenous and mäerl communities but it remains ineffective in the current scenario of a lack of relevant geospatial data (UNEP-MAP-RAC/SPA 2008, Salomidi et al. 2012). Although some efforts have been made to increase information on the distribution of this sensitive habitat (Georgiadis et al. 2009, Giakoumi et al. 2013, Martin et al. 2014), knowledge of the geographical and depth distribution of coralligenous assemblages as well as their biodiversity and its relation to their functioning is still needed for their conservation and sustainable use (UNEP-MAP-RAC/SPA 2009, European Commission 2011, Pergent 2011). The current situation is not helped by the fragmented geopolitical scenario characterizing the Mediterranean basin, with weak, uncoordinated, conflicting approaches or non-existent regulatory frameworks, policy mechanisms and enforcement (Fraschetti et al. 2011). Improving the current and future monitoring of marine biodiversity is essential in order to implement the Marine Strategy Framework Directive (MSFD) and to achieve Good Environmental Status (GES). In addition to enhancing regional cooperation, there is a need to further develop innovative and cost-effective monitoring methods and to incorporate state-of-the-art technological developments into current monitoring practices (Patrício et al. 2014).

Habitat mapping is crucial in order to obtain reliable estimates of the total area occupied by each habitat, so as to reach the required conservation targets and to implement appropriate management measures (UNEP-MAP-RAC/SPA 2008, Costello 2009). A bibliographic database plays a major role in the study of habitat distribution and its changes over time. In some Mediterranean regions, information on coralligenous distribution is available in the literature but its reliability must be estimated (Leriche et al. 2001). Acoustic technologies are increasingly being used for monitoring benthic habitats (Zapata-Ramirez et al. 2013), and those used for mapping coralligenous communities normally include side-scan sonars and multibeam sonars (Bonacorsi et al. 2012, Gordini et al. 2012). Acoustic mapping using multibeam echo sounders allows us to infer seafloor topography, and therefore the geomorphologies on which coralligenous assemblages thrive, and the best locations for ground truthing. The European Commission decision on descriptors for the MSFD states that data of geographic information systems (GIS) are a prerequisite for ecosystem-based management of human activities and for developing related spatial tools. Modelling and mapping using GIS provide the basis for informed decision making (Sardá et al. 2012).

In this work we combined a literature review, acoustic mapping and in situ observations to (i) build a map of the distribution of coralligenous assemblages in Liguria (NW Italy) using GIS; (ii) characterize their biology and geomorphology and study the influence of geomorphology and light conditions on biological features; and (iii) consider the main pressures affecting coralligenous assemblages and provide some management recommendations.

\section{MATERIALS AND METHODS}

\section{Study area}

The Ligurian coast falls into the Ligurian Sea, the northernmost part of the western Mediterranean Sea, with $350 \mathrm{~km}$ of arch-shaped coastline from Ventimiglia at the west border with Provence-AlpesCôte d'Azur (France) to La Spezia at the east border with Tuscany, Italy. Almost two thirds of the coast is composed of cliffs and promontories alternating with sandy to gravelly pocket beaches, especially along the Eastern Riviera. Soft coasts are less developed and are typically found adjacent to small coastal plains along the Western Riviera (Cattaneo-Vietti et al. 2010, Rovere 2011).

\section{Literature review and database creation}

We combined a literature review, acoustic mapping and in situ observations to build a data layer of coralligenous presence using the ArcGIS ${ }^{\circledR}$ software by Esri 
Table 1. - Scores of the dependability index (up to $5+5$ points) from the literature.

\begin{tabular}{ll}
\hline Geospatial positioning & Scores \\
\hline very approximate descriptive spatial information & 1 \\
descriptive spatial information with selected terrestrial points and bathymetric data & 2 \\
descriptive spatial information and acoustic mapping (multibeam echo sounder) & 3 \\
GPS coordinates and acoustic mapping (multibeam echo sounder) & 4 \\
files already georeferenced & 5 \\
\hline Data acquisition & 1 \\
\hline fishing material & 3 \\
recreational diving before 2000 & 4 \\
scientific diving before 2000 & 5 \\
recreational diving after 2000 & \\
scientific diving after 2000 & \\
\hline
\end{tabular}

(Environmental Systems Resource Institute), ArcMap 10.2 (www.esri.com). The existing literature was collected from scientific publications, technical reports ("grey literature"), diving and fishing books; we also considered unpublished in situ observations by experts and recreational divers (Cánovas-Molina et al. 2014). In order to estimate the reliability of the literature reviewed, a dependability index (DI) was applied, considering two parameters: geospatial positioning (five points) and method adopted for data acquisition (five points) (Table 1). The DI was not calculated for documents taken from the literature reviews because of the variety of methods used for data acquisition. A score of 1 for at least one of the parameters measured in the DI, was considered the critical value for low dependability and therefore rejection. Where digital spatial information was not available, polygons of presence of coralligenous assemblages were created by extracting spatial information from textual descriptions, helped by acoustic mapping (multibeam echo sounder) provided by Regione Liguria, when available. We carried out ground truthing through SCUBA diving at selected sites (Vado Ligure, Cogoleto, Arenzano and Punta Manara), following expert divers' observations and/ or seafloor topography revealed by multibeam echo sounder.

\section{Database analysis}

A list of characteristic sessile megabenthos species of coralligenous assemblages, identified from the literature review and in situ observations, was compiled. Facies were identified following the EUNIS Habitat Classification (Davies et al. 2004). The habitat classification developed and managed by the European Topic Centre for Nature Protection and Biodiversity (ETC/ NPB in Paris) provides a comprehensive typology for the habitats of Europe and its adjoining seas. EUNIS habitats are arranged in a hierarchy, from level 1 to 4 for marine habitats. Information on the most conspicuous species was used to identify the facies for each site with coralligenous.

Geomorphotypes where coralligenous assemblages in Liguria thrive were identified using multibeam echo sounder, when available, and textual descriptions from the literature gathered. Four geomorphotypes were considered: i) cliffs, vertical or near-vertical walls from a steep rock face, either active (plunging cliffs) or inactive (paleocliffs), ending occasionally in a flat bottom; ii) rockfalls, sets of masses of rocks of different sizes and shapes that lay on a bedding plane that originated from the face collapse of the cliff; and iii) shoals, isolated outcrops surrounded by sand or biodetrital sediments, which originated through past erosional events of the cliff, sea level rise and deposition of sediments.

To study the influence of incident light on coralligenous assemblages, we calculated incident light values on coralligenous assemblages from satellite imagery and long term-Secchi Disc records in Liguria available for the Portofino coastal area (Rapallo, Genoa). Percent light values of surface irradiance at each station in Portofino were calculated using standard methods with the formula $E_{z}=E_{0} e^{-k z}$ (Kirk 1994), where $E_{z}$ is the irradiance at depth $\mathrm{z}, \mathrm{E}_{0}$ is the surface irradiance, $\mathrm{K}$ is the vertical attenuation coefficient and $\mathrm{z}$ is the depth. $\mathrm{K}$ was approximate to $\mathrm{K}_{\mathrm{dPAR}}$ and obtained using Secchi Disc transparency records (January 2002-December 2012) using the formula $\mathrm{K}_{\mathrm{dPAR}}=1.7 / \mathrm{Secchi}$ Depth (m). $\mathrm{E}_{0}$ was approximated to photosynthetically active radiation and obtained from Goddard Earth Sciences Data and Information Services Centre (GES DISC) Interactive Online Visualization and Analysis Infrastructure, “Giovanni”" (January 2002-December 2012). Percent light values of surface irradiance on facies of coralligenous assemblages for each station were calculated as the mean value among incident light values at the shallowest and the deepest distribution. To test the influence of incident light on the distribution of coralligenous facies in Portofino, a one-way ANOVA was applied.

Information on presence of mechanical and biological pressures, as well as signs of mass mortality events due to water temperature increasing, was reported for each site with coralligenous assemblages.

\section{RESULTS}

\section{Literature reliability}

From 1937 to date, 58 documents described some aspects of the coralligenous habitat in Liguria (Supplementary material Table S1), mainly scientific papers or technical reports written in Italian. The Eastern Riviera and Marine Protected Areas (MPAs), i.e. Portofino (Rapallo, Genoa), Punta Mesco (Cinque Terre, La Spezia), and Isole di Portovenere (La Spezia), were among the most studied localities, accounting for $70 \%$ and $58 \%$ of the documents respectively. Data were 


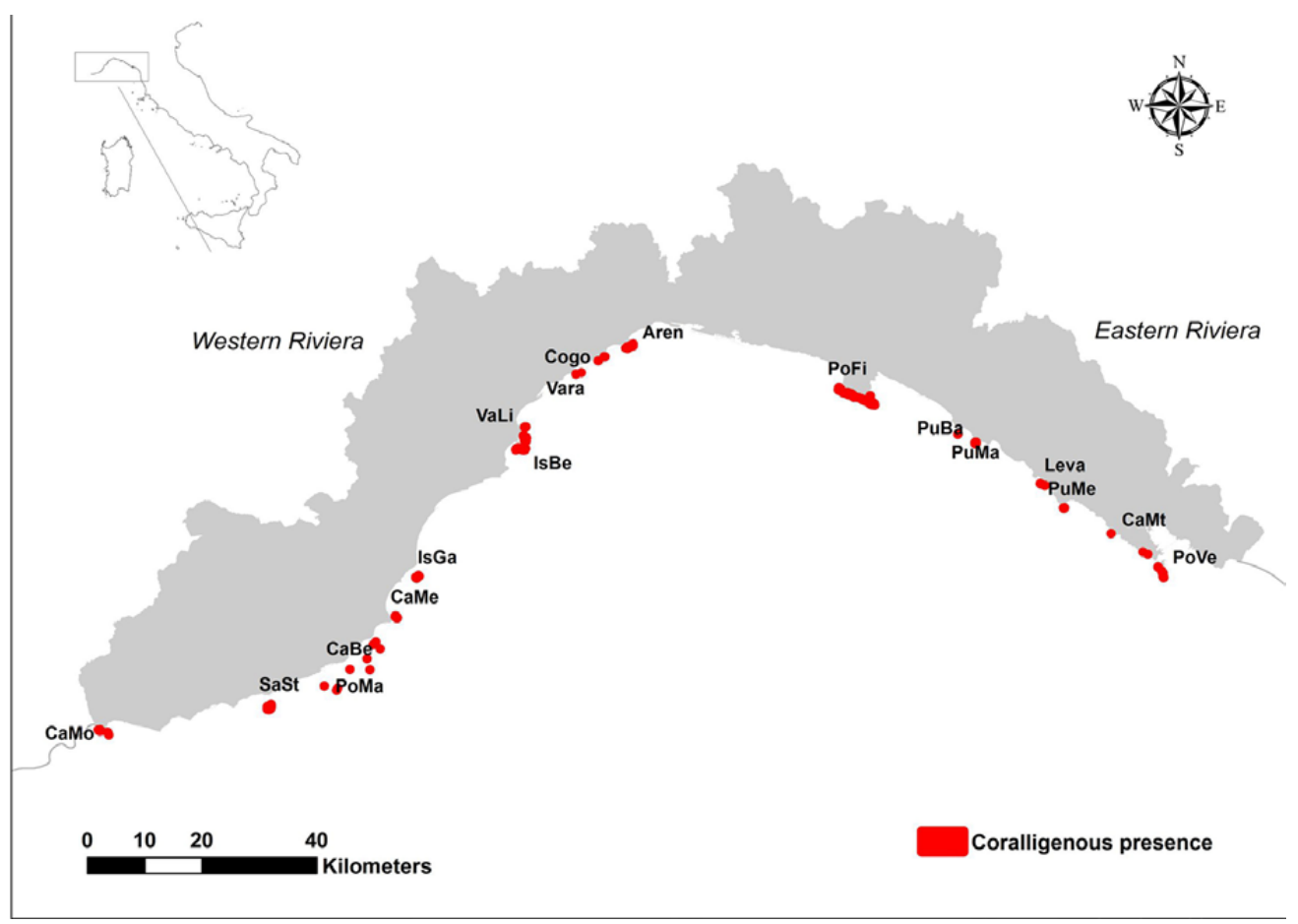

Fig. 1. - Presence of coralligenous assemblages in Liguria. To make small-scale presence visible, boundaries of polygon features have been artificially enhanced. Surface areas covered by these habitats appear much larger than they are in reality. CaMo, Capo Mortola; SaSt, Santo Stefano; PoMa, Porto Maurizio; CaBe, Capo Berta; CaMe, Capo Mele; IsGa, Isola Gallinara; IsBe, Isola Bergeggi; VaLi, Vado Ligure; Vara, Varazze; Cogo, Cogoleto; Aren, Arenzano; PoFi, Portofino; PuMa, Punta Manara; PuBa, Punta Baffe; Leva, Levanto; PuMe, Punta Mesco; CaMt, Capo Montenegro; PoVe, Portovenere.

acquired mainly by means of scientific SCUBA diving during the last two decades. Acoustic mapping was available for 10 localities. Eleven documents showed score 1 for at least one of the parameters of the DI and therefore have low dependability.

\section{Distribution of coralligenous assemblages}

A total of 90 sites within 18 localities were found to have coralligenous assemblages with an extent of 130.9 ha (Fig. 1 and Supplementary material Table S2). Seven localities (59.6 ha) were found along the Eastern Ligurian Riviera and 11 localities (71.3 ha) along the Western Riviera, the furthest location being $4 \mathrm{~km}$ from the coast at Capo Berta (Imperia) and the closest near the shoreline at Portofino. Regional and National protection laws applied for 48.3 ha (37\%) situated in Portofino, Cinque Terre and Portovenere.

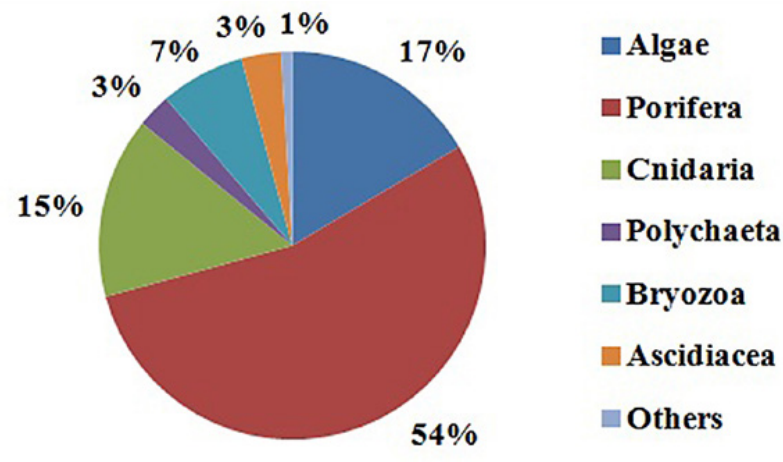

Fig. 2. - Taxonomic composition of coralligenous sessile megabenthos in Liguria.
The shallowest coralligenous assemblages in Liguria were those of Portovenere and Portofino at $10 \mathrm{~m}$ depth, the deepest that of Bergeggi at $113 \mathrm{~m}$ depth.

\section{Biology, geomorphology and incident light values}

A preliminary attempt to estimate the total number of sessile megabenthos taxa in the Ligurian coralligenous habitat is presented in Supplementary material Table S3. Sponges were the dominant group in terms of species richness (Fig. 2). The literature review permitted us to identify 12 facies of coralligenous communities (Table 2).

Table 2. - Population units identified in coralligenous assemblages of Liguria. *massive/erect sponges includes Spongia lamella, Sarcotragus foetidus, Scalarispongia scalaris, Axinella polypoides, Chondrosia reniformis and/or Petrosia ficiformis.

EUNIS Habitat 2004: A4.26 Mediterranean coralligenous communities moderately exposed to hydrodynamic action

A4.261 Association with Cystoseira zosteroides

A4.266 Association with Mesophyllum lichenoides

A4.269 Facies with Eunicella cavolini

A4.26A Facies with Eunicella singularis

A4.26B Facies with Paramuricea clavata

A4.26C Facies with Parazoanthus axinellae

EUNIS Habitat 2004: A4.32 Mediterranean coralligenous communities sheltered from hydrodynamic action

A4.322 Facies with Leptogorgia sarmentosa

Not included in the EUNIS Habitat 2004

Facies with Eunicella verrucosa

Facies with Leptopsammia pruvoti

Facies with massive/erect sponges*

Facies with Corallium rubrum

Facies with Pentapora fascialis 

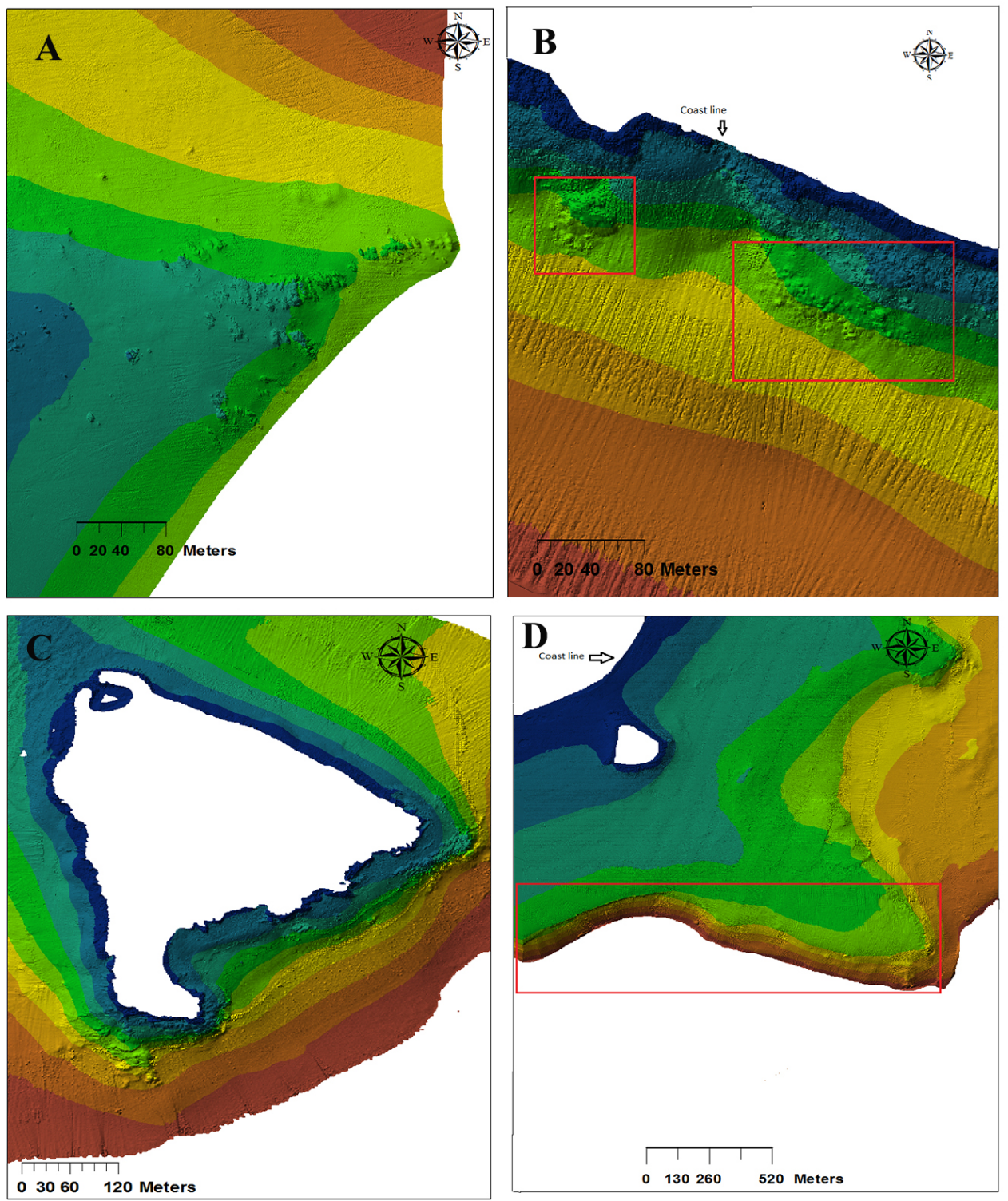

Fig. 3. - Geomorphotypes found in Liguria. A, Shoals of Vado Ligure. B, Rockfalls of Casa del Sindaco, Portofino. C, Plunging cliff of Isola Gallinara. D, Paleocliff of Secca dei Maledetti, Isola di Bergeggi.

Table 3. - Distribution of coralligenous facies on the different geomorphotypes in Liguria (values in hectares). N/A, no data available.

\begin{tabular}{|c|c|c|c|c|}
\hline & Plunging cliff & Paleocliff & Rockfalls & Shoals \\
\hline Corallium rubrum & 4.84 & & & \\
\hline Cystoseira zosteroides & & & & 1.30 \\
\hline Eunicella cavolini & 3.88 & 0.71 & & 2.33 \\
\hline Eunicella singularis & 0.91 & & & 0.58 \\
\hline Eunicella spp. & 0.91 & & & 3.86 \\
\hline Eunicella verrucosa & & & & 1.14 \\
\hline Leptogorgia sarmentosa & 6.54 & & & 0.21 \\
\hline Leptopsammia pruvoti & 0.43 & & & \\
\hline Massive/erect sponges & 2.54 & & & 2.69 \\
\hline Mesophyllum lichenoides & & & & 0.29 \\
\hline N/A & 1.03 & & & 0.94 \\
\hline Paramuricea clavata & 11.02 & 29.11 & 17.86 & 36.86 \\
\hline Parazoanthus axinellae & & & & 0.06 \\
\hline Pentapora fascialis & 0.46 & & & 0.29 \\
\hline Total & 32.56 & 29.82 & 17.86 & 50.55 \\
\hline
\end{tabular}

In Liguria four different coralligenous geomorphotypes were identified (Fig. 3). Shoals were the dominant morphology in Liguria in terms of extent, with $50.6 \mathrm{ha}$, and were mainly represented in the Western
Riviera. Plunging cliffs, paleocliffs and rockfalls covered 32.6, 29.8 and 17.9 ha, respectively (Table 3). Paleocliffs and rockfalls were mainly colonized by facies with Paramuricea clavata. In fact, this facies 


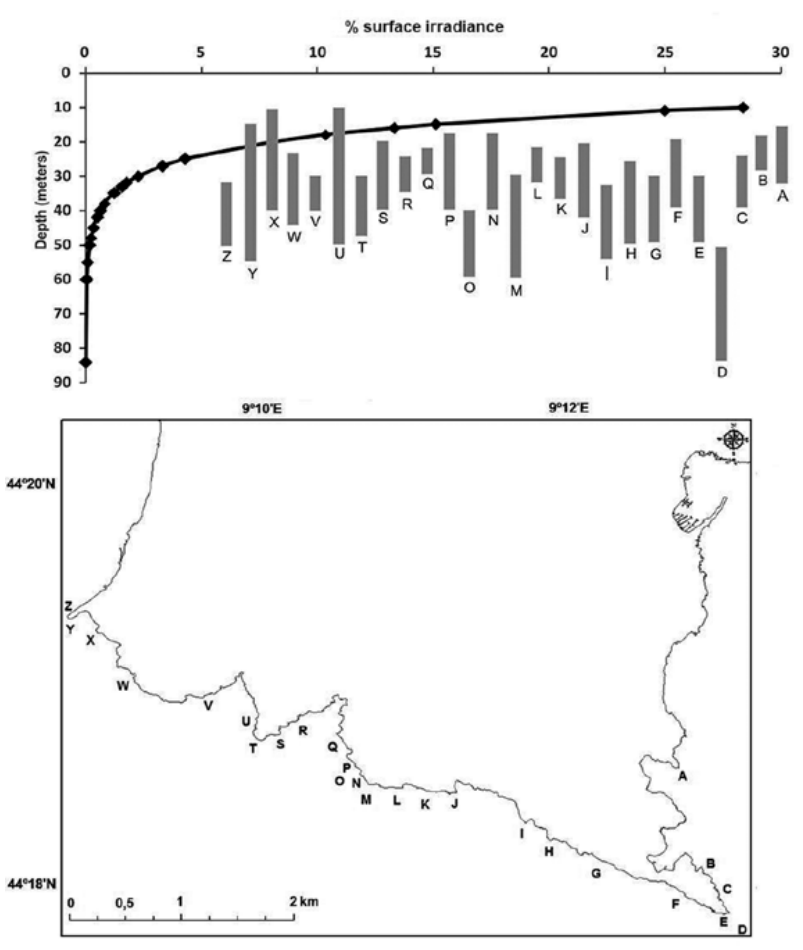

Fig. 4. - Incident light values on coralligenous assemblages of Portofino. A, Punta Cervara; B, Punta Coppo; C, Punta dell'Aurora; D, Dorsale Portofino; E, Punta Faro; F, Chiesa San Giorgio; G, Casa del Sindaco; H, Punta Vessinaro; I, Punta dell'Altare; J, Punta Fregante; K, Testa del Leone; L, Scoglio del Raviolo; M, Secca Gonzatti; N, Punta Carega; O, Scogliera del Dragone; P, Tetto del Dragone; Q, Cristo degli Abissi; R, San Fruttuoso; S, Punta Volpe; T, Punta Torretta; U, Cala dell'Oro Est; V, Cala dell'Oro Ovest; W, Punta Bussago; X, Punta Targuetta; Y, Secca dell'Isuela; Z, Punta Chiappa.

was the most conspicuous, found in all geomorphotypes with the highest extension. Units of assemblages with Mesophyllum lichenoides, Parazoanthus axinellae, Cystoseira zosteroides and Eunicella verrucosa showed a more constrained distribution, being found only on shoals.

In Portofino, incident light values on coralligenous communities varied from $0.003 \%$ to $28.37 \%$ of surface irradiance (Fig. 4). Eight facies of coralligenous assemblages thrived in Portofino promontory at different $\%$ values of surface irradiance (Fig. 5). A one-way ANOVA on incident light values showed significant differences between the facies with Paramuricea clavata, Eunicella cavolini, Corallium rubrum and Leptogorgia sarmentosa $(\mathrm{p}<0.01, \mathrm{~F}=6.13, \mathrm{df}=3)$. Facies with Eunicella cavolini showed the highest distribution range of incident light values. On the other hand, Corallium rubrum, Paramuricea clavata and Leptogorgia sarmentosa thrived on lower and narrower ranges of light conditions.

\section{Main pressures}

Pressures reported in the literature were mainly due to fishing activities, such as the presence of abandoned gears such as nets, traps and "palamiti" (a type of longliner). Other pressures were anchors, plastic bags, invasive species such as the macroalgae Caulerpa $c y$ -

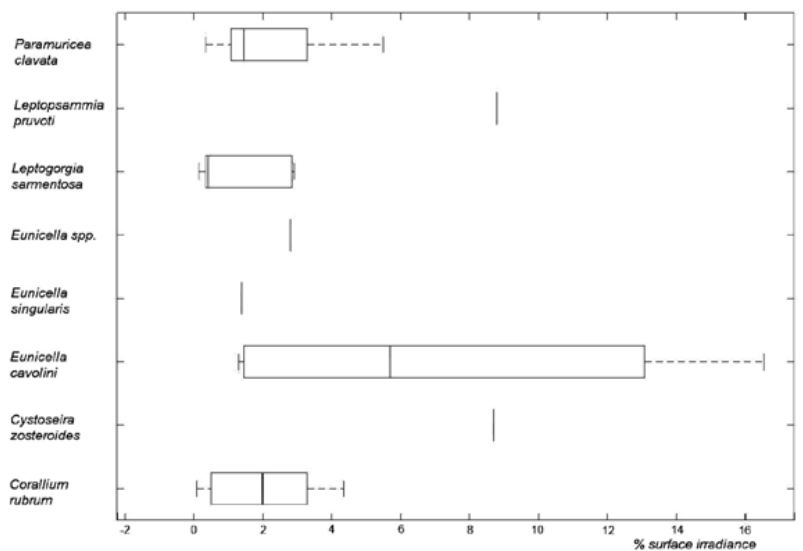

Fig. 5. - Incident light values for the different facies thriving at Portofino promontory.

lindracea and Womersleyella setacea, occasional mucilaginous events, and mass mortality events linked to climate warming. In Liguria, evidence of one or more such pressures was found in 30 of 90 sites.

\section{DISCUSSION}

\section{Database of coralligenous assemblages}

A total of 47 documents describing aspects of coralligenous habitats in Liguria were considered reliable after applying the DI for literature, and were therefore used to assess the distribution, biology, geomorphology and pressures. As digital spatial information and GPS positioning were scarce in the literature review, combining it with acoustic mapping and in situ observations helped improve accurate positioning on a GIS platform. Literature dealing with coralligenous assemblages in Liguria is more detailed for the Eastern Riviera, accounting for $70 \%$ of the documents, where their distribution is mainly associated with cliffs. The Western Riviera has been poorly studied and rarely characterized due to its particular distribution on isolated rocky outcrops of little extent found patchily along the coast.

\section{Distributional, biological and geological aspects}

Coralligenous habitats can be defined as highly heterogeneous systems, where the environmental variables together with distribution and abundances of taxa can differ greatly on both a geographical and a local (tens of metres) scale (Ferdeghini et al. 2000, Balata et al. 2005, Virgilio et al. 2006). The coralligenous assemblages in Liguria therefore show high spatial, morphological and biological variability (Fig. 6).

The shallowest distribution of coralligenous communities in Liguria was found in Portovenere, where they developed from 10 to $30 \mathrm{~m}$ depth associated with low light irradiance. Sediment load coming from the Magra River, located about $10 \mathrm{~km}$ away, explains the high turbidity in the water, with Secchi Disc values of $6.2 \pm 1.6 \mathrm{~m}$ (Bassano et al. 2000). Twelve facies were identified in the Ligurian coralligenous assemblages. 


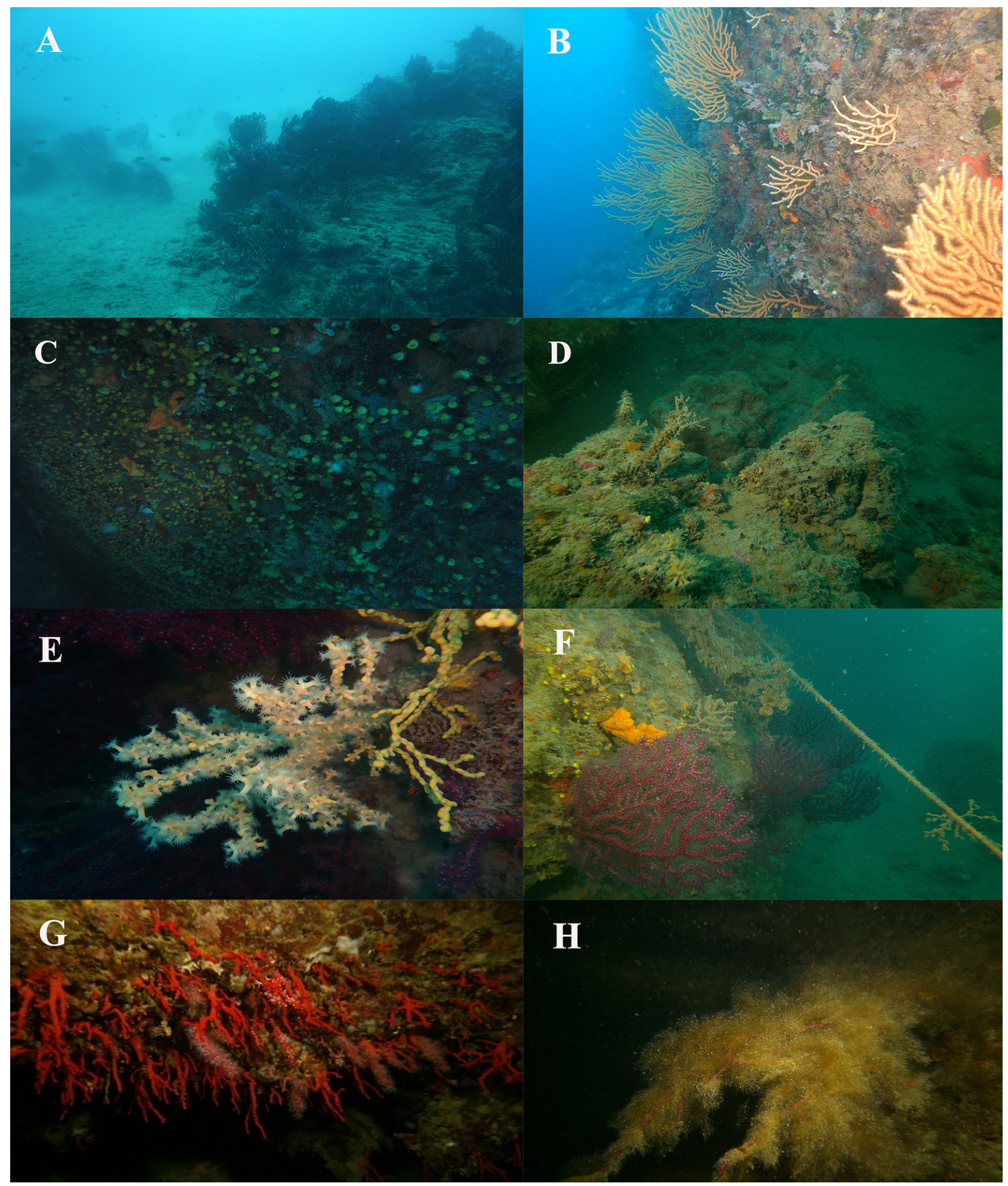

Fig. 6. - Coralligenous assemblages in Liguria. A, facies with Paramuricea clavata thriving on shoal geomorphotype (Corallo Nero, Vado Ligure) at $32 \mathrm{~m}$ depth. B, facies with Eunicella cavolini on cliff geomorphotype (Cala dell'Oro, Portofino) at $14 \mathrm{~m}$ depth. C, Facies with Leptopsammia pruvoti (Punta Cervara, Portofino) at $18 \mathrm{~m}$ depth. D, facies with massive/erect sponges (Punta Manara) at $36 \mathrm{~m}$ depth. E, Savalia savaglia colony (Punta Manara) at $39 \mathrm{~m}$ depth. F, presence of lost fishing gears (Punta Manara) at $35 \mathrm{~m}$ depth. G, Facies with Corallium rubrum (Punta dell'Altare, Portofino) at $38 \mathrm{~m}$ depth. H, presence of mucilaginous event (Punta dell'Altare, Portofino) at $38 \mathrm{~m}$ depth.

Eunicella verrucosa and massive/erect sponges could be assigned to EUNIS Habitat 2004 classification as A4.32 Mediterranean coralligenous communities sheltered from hydrodynamic action and Corallium rubrum, Leptopsammia pruvoti and Pentapora fascia- lis to A4.26 Mediterranean coralligenous communities moderately exposed to hydrodynamic action. An update of the EUNIS list is needed in order to consider the real biological heterogeneity of coralligenous communities (Bianchi et al. 2010). 
In the marine environment, light is a key environmental variable coupling physics to biogeochemistry and ecology. According to Ballesteros (1992), coralligenous communities develop between $0.05 \%$ and $3 \%$ of the surface irradiance. "Dorsale Portofino" reaches light values below $0.05 \%(0.003-0.14 \%)$ where coralligenous assemblages grow on shoals between 52 and $84 \mathrm{~m}$ depth and are dominated by suspension feeders: gorgonians, antipatharians and sponges with few calcareous concretions. Light values greater than $3 \%$ correspond to coralligenous communities above $27 \mathrm{~m}$ depth with a high frequency of so-called "precoralligenous" species (Bianchi et al. 2004), such as Cladocora caespitosa, Codium bursa, Flabellia petiolata, Halimeda tuna and Sarcotragus fasciculatus as components of coralligenous communities with high light tolerance.

In coralligenous assemblages two main geomorphologies have been described (Pérès and Picard 1964, Ballesteros 2006): i) banks, which can fall into the coralligène de plateau definition and consist of flat frameworks with a variable thickness $(0.5$ to $4 \mathrm{~m})$ built on horizontal substrate; and ii) rims, which can fall into the coralligène de l'horizon inférieur de la roche littorale definition and consist of structures developed along vertical cliffs with a thickness range of 0.2 to $2 \mathrm{~m}$. Some problems arise in trying to classify coralligenous formations into these two categories due to the high variability of the build-ups in terms of geometry, dimension, areal distribution and settled substrate (Bracchi et al. 2014). In Liguria, the high variability of origin, extension, slope and shape of geomorphologies led us to identify, as did Laborel (1961), four different geomorphotypes: cliffs (paleocliffs and plunging cliffs), shoals, and rockfalls.

\section{Main pressures}

Pressures were found at $33 \%$ of the sites, mainly due to professional and recreational fishing activities, mass mortality events, presence of invasive species and mucilaginous events. In Portofino, a major cause of mortality in Paramuricea clavata is damage by fishing lines, followed by the attachment of numerous epibionts (Bavestrello et al. 1997). Coralligenous habitats have been invaded by alien species such as Caulerpa cylindracea (Piazzi et al. 2007) and/or Womersleyella setacea (Gatti et al. 2015), with consequent loss of structure and biodiversity of the original assemblages. In the late summer of 1999, when a sudden increase in sea water temperature in the Ligurian Sea occurred down to 50 $m$ depth, an extensive mortality of gorgonians and other epibenthic organisms was observed in Liguria: the proportion of affected gorgonians ranged from $60 \%$ to $100 \%$, suggesting that millions of sea fans died (Cerrano et al. 2000).

\section{Management recommendations}

We highly recommend including coralligenous habitats in the EU Habitats Directive (92/43/EEC) as a priority natural habitat type. In addition, MPAs must be established in order to protect representative coralligenous assemblages by applying the protection and management measures recommended by Articles 6 and 7 of the SPA protocol (Ballesteros $2009)$. In Liguria, 48.3 ha $(37 \%)$ of coralligenous habitats are inside national or regional MPAs. Among the 82.6 ha of coralligenous assemblages without a specific conservation plan, the assemblages of Bergeggi and the deep (>70 m) assemblages of Portofino lie outside the limits of the MPAs of "Isola di Bergeggi" and "Portofino", respectively. Therefore, we recommend the extension of the two MPAs in order to include them.

To enforce the MSFD and achieve GES, we suggest the implementation of a common monitoring programme for coralligenous habitats of Liguria. This monitoring programme should fulfil the following requirements:

- It should take into account their high geographic and biological heterogeneity and therefore be applied also in the poorly studied shoals of the Western Riviera.

- It should be able to assess ecological status and pressures and their linkage. Ecological status assessment should consider coralligenous structure (e.g. species richness and percentage cover), as well as functioning (e.g. connectivity and population dynamics).

- It should include new methods and technologies. The use of photo-video mosaicing can provide information on both landscape level (metre-scale) maps and high-resolution (sub-millimetre) images of individual colonial organisms (Reid et al. 2010). If further validated, the photo mosaic techniques and $3 \mathrm{D}$ reconstructions would provide a cost-effective tool for assessing ecological status and monitoring changes due to natural or anthropogenic disturbance in these environments (Zapata-Ramirez et al. 2013).

Combining a literature review (scientific publications, unpublished documents and books), acoustic mapping and in situ observations (ground truthing and personal communications) on a GIS platform resulted in an efficient, powerful tool for the assessment of the distribution and heterogeneity of coralligenous communities and the pressures affecting them. This methodology could give information on the real extent and diversity of these assemblages to help governments and stakeholders implement appropriate management measures to guarantee sustainable development of coastal areas.

\section{ACKNOWLEDGEMENTS}

The study was carried out within the framework of the project PRIN 2010-11 Bioconstructions funded by the Italian Ministero dell'Istruzione, dell'Università e della Ricerca. We wish to thank the Regione Liguria for giving us multibeam data and bibliographic information. We thank Paolo Povero (Genoa) and Felice Zanini (Genoa) for providing information and Roy Armstrong, William Hernández (Puerto Rico), Daniel Mateos Molina (Murcia) and Matteo Vacchi (Marseille) for their advice. 


\section{REFERENCES}

Agnesi S., Annunziatellis A., Cassese M.L., et al. 2008. Synthesis of the cartographic information on the coralligenous assemblages and other biogenic calcareous formations in the Mediterranean Sea. In: Pergent-Martini C. and Brichet M. (eds), Avenant N³/2008/RAC/SPA en référence au Mémorandum de coopération $\mathrm{N}^{\circ} 6 / 2002 / \mathrm{RAC} / \mathrm{SPA} .50$ pp.

Balata D., Piazzi L., Cecchi E., et al. 2005. Variability of Mediterranean coralligenous assemblages subject to local variation in sediment deposition. Mar. Environ. Res. 60: 403-421. http://dx.doi.org/10.1016/j.marenvres.2004.12.005

Baldacconi R., Corriero G. 2009. Effects of the spread of the alga Caulerpa racemosa var. cylindracea on the sponge assemblage from coralligenous concretions of the Apulian coast (Ionian Sea, Italy). Mar. Ecol. 30: 337-345. http://dx.doi.org/10.1111/j.1439-0485.2009.00282.x

Ballesteros E. 1992. Els vegetals i la zonació litoral: espècies, comunitats i factors que influeixen en la seva distribució. Arx. Sec. Cièn. Inst. Est. Catalans. 101: 1-616.

Ballesteros E. 2006. Mediterranean coralligenous assemblages: a synthesis of present knowledge. Oceanogr. Mar. Biol. Ann. Rev. 44: 123-195. http://dx.doi.org/10.1201/9781420006391.ch4

Ballesteros E. 2009. Threats and conservation of coralligenous assemblages. In: Pergent-Martini C. and Brichet M. (eds), Proceedings of the 1st Mediterranean symposium on the conservation of the coralligenous and other calcareous bio-concretions. RAC/SPA Publ. Tunis, pp. 25-27.

Bassano E., Boniforti R., Pezzani A. 2000. Parametri meteorologici e idrologici. In: Peroni C. (ed), Sistema informativo e di monitoraggio marino costiero della provincia della Spezia. ENEA, Rapp. Tec, pp. 17-55

Bavestrello G., Cerrano C., Zanzi D., et al. 1997. Damage by fishing activities to the gorgonian coral Paramuricea clavata in the Ligurian Sea. Aquat. Conserv. Mar. Freshw. Ecosyst. 7: 253-262.

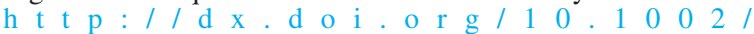
(SICI) 1099-0755(199709)7:3<253::AID-AQC243>3.0.CO;2-1

Bianchi C.N., Boero F., Fraschetti S., et al. 2004. Il popolamento sommerso. In: Minelli A. (eds), Coste marine rocciose: la vita tra rocce e salsedine. Ministero dell'Ambiente e della tutela del Territorio e del Mare, Roma, and Museo Friulano di Storia Naturale, Udine, Quaderni Habitat, 7: 105-134.

Bianchi C.N., Morri C., Navone A. 2010. The biological assemblages of submerged rocky reefs in the Marine Protected Area of Tavolara Punta Coda Cavallo (north-east Sardinia, Italy). Sci. Rep. Port-Cros Nat. Park, 24: 39-85.

Bonacorsi M., Pergent-Martini C., Clabaut P., et al. 2012. Coralligenous 'atolls': Discovery of a new morphotype in the Western Mediterranean Sea, Comptes. Rendus. Biologie 335(10-11): 668-672. http://dx.doi.org/10.1016/j.crvi.2012.10.005

Bracchi V.A., Basso D., Savini A., et al. 2014. Coralligenous: insights for a new geomorphological definition. In: PergentMartini C. and Brichet M. (eds), Proceedings of the 2nd Mediterranean symposium on the conservation of the coralligenous and other calcareous bio-concretions. RAC/SPA Publ. Tunis, pp. 49-54.

Cánovas Molina A., Montefalcone M., Canessa M., et al. 2014. Proceedings of the 2 nd Mediterranean symposium on the conservation of the coralligenous and other calcareous bio-concretions. In: Pergent-Martini C. and Brichet M. (eds). RAC/SPA Publ. Tunis, pp. 55-60.

Cattaneo-Vietti R., Albertelli G., Aliani S., et al. 2010. The Ligurian Sea: present status, problems and perspectives. Chem. Ecol. 26: 319-340. http://dx.doi.org/10.1080/02757541003689845

Cerrano C., Bavestrello G., Bianchi C.N., et al. 2000. A catastrophic mass-mortality episode of gorgonians and other organisms in the Ligurian Sea (North-western Mediterranean), summer 1999. Ecol. Lett. 3: 284-293. http://dx.doi.org/10.1046/j.1461-0248.2000.00152.x

Council European Communities. 2006. Council Regulation (EC) $1967 / 2006$ of 21 December 2006 concerning management measures for the sustainable exploitation of fishery resources in the Mediterranean Sea. Off. J. EU. L409, 11-84.

Costello M.J. 2009. Distinguishing marine habitat classification concepts for ecological data management. Mar. Ecol. Prog. Ser. 397: 253-268.

http://dx.doi.org/10.3354/meps08317
Davies C.E., Moss D., Hill M.O. 2004. EuNIS Habitat Classification revised 2004. Report to the European Topic Centre on Nature Protection and Biodiversity, European Environmental Agency, October 2004.

European Commission. 2011. Commission staff working paper. Relationship between the initial assessment of marine waters and the criteria for good environmental status, European Commission, Brussels, 14.10.2011 SEC, 95 pp.

Ferdeghini F., Acunto S., Cocito S., et al. 2000. Variability at different spatial scales of a coralligenous assemblage at Giannutri Island (Tuscan Archipelago, northwest Mediterranean). Hydrobiologia 440: 27-36. http://dx.doi.org/10.1023/A:1004124423718

Fraschetti S., Guarnieri G., Bevilacqua S., et al. 2011. Conservation of Mediterranean habitats and biodiversity countdowns: What information do we really need? Aquat. Conserv. Mar. Freshw. Ecosyst. 21: 299-306. http://dx.doi.org/10.1002/aqc.1185

Gatti G., Bianchi C.N., Parravicini V., et al. 2015. Ecological change, sliding baselines and the importance of historical data: lessons from combining observational and quantitative data on a temperate reef over 70 years. PLoS One, 10 (2): e0118581. http://dx.doi.org/10.1371/journal.pone.0118581

Georgiadis M., Papatheodorou G., Tzanatos E., et al. 2009. Coralligene formations in the eastern Mediterranean Sea: Morphology, distribution, mapping and relation to fisheries in the southern Aegean Sea (Greece) based on high-resolution acoustics. J. Exp. Mar. Biol. Ecol. 368: 44-58. http://dx.doi.org/10.1016/j.jembe.2008.10.001

Giakoumi S., Sini M., Gerovasileiou V., et al. 2013. Ecoregionbased conservation planning in the Mediterranean: Dealing with large scale heterogeneity. PLoS One 8: e76449. http://dx.doi.org/10.1371/journal.pone.0076449

Gordini E., Falace A., Kaleb S., et al. 2012. Methane related carbonate cementation of marine sediments and related macroalgal coralligenous assemblages in the Northern Adriatic Sea. Elsevier, London, 183-198.

Kirk J.T.O. 1994. Light and Photosynthesis in Aquatic Ecosystems. Cambridge Univ. Press, $500 \mathrm{pp}$ http://dx.doi.org/10.1017/CBO9780511623370

Laborel J. 1961. Le concrétionnement algal "coralligène" et son importance géomorphologique en Méditerranée. Rec. Trav. Stat. Mar. Endoume 23 (37): 37-60.

Laborel J. 1987. Marine biogenic constructions in the Mediterranean, a review. Sci. Rep. Port-Cros natl. Park. Fr., 13: 97-127.

Laubier L. 1966. Le coralligène des Albères. Monographie biocénotique. Ann. Inst. Océanogr. Paris 43: 137-316.

Leriche A., Boudouresque C. F., Bernard G., et al. 2001. A onecentury suite of seagrass bed maps: can we trust ancient maps? Estuar. Coast. Shelf Sci. 59: 353-362. http://dx.doi.org/10.1016/j.ecss.2003.09.007

Linares C., Zabala M., Garrabou J., et al. 2010. Assessing the impact of diving in coralligenous communities: The usefulness of demographic studies of red gorgonian populations. Sci. Rep. Port-Cros natl. Park, Fr., 24: 161-184.

Marion A.F. 1883. Esquisse d'une topographie zoologique du Golfe de Marseille. Ann. Mus. Marseille 1: 6-108.

Martin C.S., Giannoulaki M., De Leo F., et al. 2014. Coralligenous and maërl habitats: predictive modelling to identify their spatial distributions across the Mediterranean Sea. Sci. Rep. 4: 5073. http://dx.doi.org/10.1038/srep05073

Patrício J., Teixeira H., Borja A., et al. 2014. DEVOTES recommendations for the implementation of the Marine Strategy Framework Directive. Deliverable 1.5, DEVOTES project. JRC92131, $71 \mathrm{pp}$.

Pérès J.M., Picard J. 1964. Nouveau manuel de bionomie benthique de la Mer Méditerranée. Rec. Trav. Stat. Mar. Endoume 14: $1-137$.

Pergent G. 2011. Proposal for the definition of standard methods for inventorying and monitoring coralligenous and maerl populations. UNEP-MAP, RAC/SPA Report. UNEP (DEPI)/MED WG.362/4. Tunis, 20 pp.

Piazzi L., Balata D., Cinelli F. 2007. Invasions of alien macroalgae in Mediterranean coralligenous assemblages. Cryptogam. Algol. 28: 289-301.

Reid R.P., Lirman D., Gracias N., et al. 2010. Application of landscape mosaic technology to complement coral reef resource mapping and monitoring. SERDP Project RC-1333, 189 pp.

Rovere A. 2011. Rocky coast in the Ligurian Sea: morphology, evolution and management aspects. $\mathrm{PhD}$ thesis, Univ. Genoa, $236 \mathrm{pp}$ 
Salomidi M., Katsanevakis S., Borja Á., et al. 2012. Assessment of goods and services, vulnerability, and conservation status of European seabed biotopes: a stepping stone towards ecosystembased spatial management. Med. Mar. Sci. 35 (1): 49-88. http://dx.doi.org/10.12681/mms.23

Sardá R., Rossi S., Martí X., et al. 2012. Marine benthic cartography of the Cap de Creus (NE Catalan Coast, Mediterranean Sea). Sci. Mar. 76(1): 159-171. http://dx.doi.org/10.3989/scimar.03101.18D

UNEP-MAP-RAC/SPA. 2008. Action plan for the conservation of the coralligenous and other calcareous bio-concretions in the Mediterranean Sea. In: Pergent-Martini C. and Brichet M. (eds), RAC/SPA Tunis, $21 \mathrm{pp}$.

UNEP-MAP-RAC/SPA. 2009. Proceedings of the 1st Mediterranean symposium on the conservation of the coralligenous and other calcareous bio-concretions. In: Pergent-Martini C. and Brichet M. (eds), RAC/SPA Tunis, 273 pp.

Virgilio M., Airoldi L., Abbiati M. 2006. Spatial and temporal variations of assemblages in a Mediterranean coralligenous reef and relationships with surface orientation. Coral Reefs 25: 265-272. http://dx.doi.org/10.1007/s00338-006-0100-2

Watling L., Norse E.A. 1998. Disturbance of the seabed by mobile fishing gear: A comparison to forest clearcutting. Conserv. Biol. 12: 1180-1197.

http://dx.doi.org/10.1046/j.1523-1739.1998.0120061180.x
Zapata-Ramirez P.A., Scaradozzi D., Sorbi L., et al. 2013. Innovative study methods for the Mediterranean coralligenous habitats. Adv. Oceanol. Limnol. 4(2): 102-119. http://dx.doi.org/10.1080/19475721.2013.849758

The following material is available through the online version of this article and at the following link:

http://www.icm.csic.es/scimar/supplm/sm04235esm.pdf

Table S1. - Literature review on coralligenous assemblages in Liguria. Scarce, scarce biological information or just focused on one species. DI (GP+DA), dependability index of literature (Geospatial Positioning + Data Acquisition).*Score $=1$ for at least one of the parameters considered in the DI.

Table S2. - Ligurian localities with coralligenous and main characteristics. N/A, No data available. * Facies not included in the EUNIS Habitat 2004 classification for Mediterranean coralligenous communities.

Table S3. - List of sessile megabenthos taxa reported by different authors for the Ligurian coralligenous community. 
Combining literature review, acoustic mapping and in situ observations: an overview of coralligenous assemblages in Liguria (NW Mediterranean Sea)

Almudena Cánovas Molina, Monica Montefalcone, Paolo Vassallo, Carla Morri, Carlo Nike Bianchi, Giorgio Bavestrello

Supplementary material 
Table S1. - Literature review on coralligenous assemblages in Liguria. Scarce, scarce biological information or just focused on one species. DI (GP+DA), dependability index of literature (Geospatial Positioning + Data Acquisition). *Score $=1$ for at least one of the parameters considered

\begin{tabular}{|c|c|c|c|c|c|c|c|}
\hline Year & Author & $\begin{array}{c}\text { Type of } \\
\text { document }\end{array}$ & Language & $\begin{array}{l}\text { Biological } \\
\text { information }\end{array}$ & Spatial information & $\begin{array}{l}\text { Method of data } \\
\text { acquisition }\end{array}$ & $\mathrm{DI}(\mathrm{GP}+\mathrm{DA})$ \\
\hline 1937 & $\begin{array}{l}\text { Tortonese E. and } \\
\text { Faraggiana R. }\end{array}$ & Scientific paper & Italian & scarce & very approximate & fishing material & $2=1 *+1 *$ \\
\hline 1958 & Tortonese E. & Scientific paper & Italian & qualitative & $\begin{array}{l}\text { terrestrial points and } \\
\text { bathymetric data }\end{array}$ & scientific diving & $6=3+3$ \\
\hline 1961 & Rossi L. & $\begin{array}{l}\text { Congress } \\
\text { contribution }\end{array}$ & French & qualitative & $\begin{array}{l}\text { terrestrial points and } \\
\text { bathymetric data }\end{array}$ & scientific diving & $6=3+3$ \\
\hline 1961 & Tortonese E. & Scientific paper & Italian & qualitative & $\begin{array}{l}\text { terrestrial points and } \\
\text { bathymetric data }\end{array}$ & scientific diving & $6=3+3$ \\
\hline 1965 & Rossi L. & Scientific paper & Italian & qualitative & $\begin{array}{l}\text { terrestrial points and } \\
\text { bathymetric data }\end{array}$ & scientific diving & $6=3+3$ \\
\hline 1965 & Rossi L. & Scientific paper & Italian & Quantitative & $\begin{array}{l}\text { terrestrial points and } \\
\text { bathymetric data }\end{array}$ & scientific diving & $6=3+3$ \\
\hline 1965 & Santi G. & Book & Italian & scarce & $\begin{array}{l}\text { terrestrial points and } \\
\text { bathymetric data }\end{array}$ & fishing material & $3=2+1 *$ \\
\hline 1967 & Fusco N. & Book & Italian & scarce & $\begin{array}{l}\text { terrestrial points and } \\
\text { bathymetric data }\end{array}$ & fishing material & $3=2+1 *$ \\
\hline 1968 & Fusco N. & Book & Italian & scarce & $\begin{array}{l}\text { terrestrial points and } \\
\text { bathymetric data }\end{array}$ & fishing material & $3=2+1 *$ \\
\hline 1972 & Fusco N. & Book & Italian & scarce & $\begin{array}{l}\text { terrestrial points and } \\
\text { bathymetric data }\end{array}$ & fishing material & $3=2+1 *$ \\
\hline 1973 & Melegari G. & Book & Italian & scarce & $\begin{array}{l}\text { terrestrial points and } \\
\text { bathymetric data }\end{array}$ & recreational diving & $5=3+2$ \\
\hline 1976 & Pansini M. et al. & Technical report & Italian & qualitative & very approximate & scientific diving & $4=1 *+3$ \\
\hline 1979 & Balduzzi A. et al. & Book & Italian & qualitative & very approximate & scientific diving & $4=1 *+3$ \\
\hline 1986 & Bavestrello G. et al. & Scientific paper & Italian & qualitative & very approximate & scientific diving & $4=1 *+3$ \\
\hline 1986 & Morri C. et al. & Scientific paper & Italian & qualitative & very approximate & scientific diving & $4=1 *+3$ \\
\hline 1989 & Peirano A. et al. & Scientific paper & Italian & Quantitative & $\begin{array}{l}\text { terrestrial points and } \\
\text { bathymetric data }\end{array}$ & scientific diving & $6=3+3$ \\
\hline 1992 & Balduzzi A. et al & $\begin{array}{l}\text { Congress } \\
\text { contribution }\end{array}$ & Italian & qualitative & $\begin{array}{l}\text { terrestrial points and } \\
\text { bathymetric data }\end{array}$ & scientific diving & $6=3+3$ \\
\hline 1992 & Peirano A. et al. & Scientific paper & Italian & Quantitative & $\begin{array}{l}\text { terrestrial points and } \\
\text { bathymetric data }\end{array}$ & scientific diving & $6=3+3$ \\
\hline 1993 & Tommei A. & Book & Italian & scarce & $\begin{array}{l}\text { terrestrial points and } \\
\text { bathymetric data }\end{array}$ & recreational diving & $5=3+2$ \\
\hline 1994 & Bavestrello G. et al. & Scientific paper & English & scarce & $\begin{array}{l}\text { terrestrial points and } \\
\text { bathymetric data }\end{array}$ & scientific diving & $6=3+3$ \\
\hline 1994 & Bianchi C.N. et al. & Technical report & Italian & qualitative & $\begin{array}{l}\text { terrestrial points and } \\
\text { bathymetric data }\end{array}$ & scientific diving & $6=3+3$ \\
\hline 1997 & Bavestrello G. et al. & Scientific paper & English & scarce & $\begin{array}{l}\text { terrestrial points and } \\
\text { bathymetric data }\end{array}$ & scientific diving & $6=3+3$ \\
\hline 1997 & Cocito S. et al. & Scientific paper & English & Quantitative & $\begin{array}{l}\text { terrestrial points and } \\
\text { bathymetric data }\end{array}$ & scientific diving & $6=3+3$ \\
\hline 1997 & Salvati E. & Thesis & Italian & Quantitative & $\begin{array}{l}\text { terrestrial points and } \\
\text { bathymetric data }\end{array}$ & scientific diving & $6=3+3$ \\
\hline 1998 & Cocito S. et al. & Scientific paper & English & scarce & $\begin{array}{l}\text { terrestrial points and } \\
\text { bathymetric data }\end{array}$ & scientific diving & $6=3+3$ \\
\hline 1999 & Relini M et al. & Technical report & Italian & qualitative & $\begin{array}{l}\text { terrestrial points and } \\
\text { bathymetric data }\end{array}$ & scientific diving & $5=2+3$ \\
\hline 2000 & Cerrano C. et al. & Scientific paper & English & quantitative & $\begin{array}{l}\text { terrestrial points and } \\
\text { bathymetric data }\end{array}$ & scientific diving & $6=3+3$ \\
\hline 2000 & $\begin{array}{c}\text { Leali-Rizzi T. and } \\
\text { Penco A. }\end{array}$ & Book & Italian & scarce & $\begin{array}{l}\text { terrestrial points and } \\
\text { bathymetric data }\end{array}$ & recreational diving & $5=3+2$ \\
\hline 2000 & Morri C. & Technical report & Italian & qualitative & $\begin{array}{l}\text { terrestrial points and } \\
\text { bathymetric data }\end{array}$ & scientific diving & $6=3+3$ \\
\hline 2000 & Peirano A. et al. & Scientific paper & English & qualitative & $\begin{array}{l}\text { terrestrial points and } \\
\text { bathymetric data }\end{array}$ & scientific diving & $6=3+3$ \\
\hline 2001 & Cerrano C. et al. & Book & English & scarce & very approximate & scientific diving & $6=1 *+5$ \\
\hline 2001 & $\begin{array}{c}\text { Leali-Rizzi T. and } \\
\text { Penco A. }\end{array}$ & Book & Italian & scarce & $\begin{array}{l}\text { terrestrial points and } \\
\text { bathymetric data }\end{array}$ & recreational diving & $6=2+4$ \\
\hline 2002 & Bianchi C.N. et al. & Technical report & Italian & qualitative & $\begin{array}{l}\text { terrestrial points and } \\
\text { bathymetric data }\end{array}$ & scientific diving & $8=3+5$ \\
\hline 2002 & Cocito S. et al. & Scientific paper & English & quantitative & GPS points & scientific diving & $9=4+5$ \\
\hline 2003 & Galliadi A. et al. & Book & Italian & scarce & $\begin{array}{l}\text { terrestrial points and } \\
\text { bathymetric data }\end{array}$ & recreational diving & $7=3+4$ \\
\hline 2003 & $\begin{array}{l}\text { Massajoli M. and } \\
\text { Barsotti G. }\end{array}$ & Book & Italian & scarce & $\begin{array}{l}\text { terrestrial points and } \\
\text { bathymetric data }\end{array}$ & recreational diving & $7=3+4$ \\
\hline 2003 & Sara G. et al. & Thesis & Italian & quantitative & GPS points & scientific diving & $9=4+5$ \\
\hline 2003 & Sara G. et al. & Scientific paper & Italian & quantitative & $\begin{array}{l}\text { terrestrial points and } \\
\text { bathymetric data }\end{array}$ & scientific diving & $8=3+5$ \\
\hline 2004 & Cattaneo-Vietti R. & Technical report & Italian & quantitative & GPS points & scientific diving & $9=4+5$ \\
\hline 2005 & Cerrano C. et al. & Scientific paper & English & scarce & $\begin{array}{l}\text { terrestrial points and } \\
\text { bathymetric data }\end{array}$ & scientific diving & $8=3+5$ \\
\hline
\end{tabular}




\begin{tabular}{|c|c|c|c|c|c|c|c|}
\hline 2006 & Bianchi C:N. et al. & Technical report & Italian & scarce & $\begin{array}{l}\text { Files already } \\
\text { georeferenced }\end{array}$ & $\begin{array}{l}\text { Recreational } \\
\text { diving }\end{array}$ & $9=5+4$ \\
\hline 2006 & Rovere A. et al. & Scientific paper & Italian & qualitative & very approximate & scientific diving & $6=1 *+5$ \\
\hline 2006 & $\begin{array}{l}\text { Rovere A. and } \\
\text { Parravicini V. }\end{array}$ & Technical report & Italian & qualitative & GPS points & scientific diving & $9=4+5$ \\
\hline 2007 & Parravicini V. et al. & Scientific paper & Italian & qualitative & $\begin{array}{l}\text { terrestrial points and } \\
\text { bathymetric data }\end{array}$ & recreational diving & $7=3+4$ \\
\hline 2007 & Previati M. et al. & Scientific paper & Italian & scarce & GPS points & scientific diving & $9=4+5$ \\
\hline 2008 & Vota P. & Thesis & Italian & qualitative & $\begin{array}{l}\text { terrestrial points and } \\
\text { bathymetric data }\end{array}$ & scientific diving & $8=3+5$ \\
\hline 2009 & Cerrano C. et al. & Technical report & Italian & quantitative & $\begin{array}{l}\text { terrestrial points and } \\
\text { bathymetric data }\end{array}$ & scientific diving & $7=2+5$ \\
\hline 2009 & Previati M. et al. & Scientific paper & Italian & quantitative & $\begin{array}{l}\text { terrestrial points and } \\
\text { bathymetric data }\end{array}$ & scientific diving & $8=3+5$ \\
\hline 2009 & Scinto A. et al. & Scientific paper & English & quantitative & $\begin{array}{l}\text { terrestrial points and } \\
\text { bathymetric data }\end{array}$ & scientific diving & $8=3+5$ \\
\hline 2010 & Bianchi C.N. et al. & Technical report & Italian & qualitative & GPS points & scientific diving & $9=4+5$ \\
\hline 2010 & $\begin{array}{c}\text { Montefalcone M. } \\
\text { et al. }\end{array}$ & Technical report & Italian & qualitative & $\begin{array}{l}\text { files already } \\
\text { georeferenced }\end{array}$ & scientific diving & $10=5+5$ \\
\hline 2011 & Previati M. & Book & Italian & quantitative & $\begin{array}{l}\text { terrestrial points and } \\
\text { bathymetric data }\end{array}$ & scientific diving & $8=3+5$ \\
\hline 2011 & Previati M. et al. & Scientific paper & Italian & quantitative & GPS points & scientific diving & $9=4+5$ \\
\hline 2012 & Cupido R. et al. & Scientific paper & English & scarce & GPS points & scientific diving & $9=4+5$ \\
\hline 2012 & ENEA & Technical report & Italian & quantitative & $\begin{array}{l}\text { terrestrial points and } \\
\text { bathymetric data }\end{array}$ & scientific diving & $8=3+5$ \\
\hline 2012 & Gatti G. et al. & Scientific paper & English & qualitative & $\begin{array}{l}\text { files already } \\
\text { georeferenced }\end{array}$ & scientific diving & $10=5+5$ \\
\hline 2012 & Previati M. et al. & Technical report & Italian & quantitative & GPS points & scientific diving & $9=4+5$ \\
\hline 2013 & Bertolino M. et al. & Scientific paper & English & qualitative & $\begin{array}{l}\text { terrestrial points and } \\
\text { bathymetric data }\end{array}$ & scientific diving & $8=3+5$ \\
\hline
\end{tabular}

\section{References}

Balduzzi A., Belloni S., Boero F., Pessani D., Pronzato R., 1979. I popolamenti bentonici. In: Andreoli M.G., Loppel S., Orsini C. (eds), Analisi di una ricerca: il Golfo di Levanto. Cassa di Risparmio della Spezia, pp. 51-65.

Balduzzi A., Bianchi C. N., Cattaneo-Vietti R., Cerrano C., Cocito S., Cotta S., Degl'inn ocenti F., Diviacco G., Morgigni M., Morri C., Pansini M., Salvatori L., Senes L., Sgorbini S., Tunesi L. 1992 Primi lineamenti di bionomia bentica dell'isola Gallinaria (Mar Ligure) Proceedings of the $10^{\circ}$ AIOL, Alassio Italy, November 1992.

Bavestrello G., Boero F. 1986. Necrosi e rigenerazione in Eunicella cavolinii in Mar Ligure. Boll. Mus. Ist. Biol. Univ. Genova. 52: 295-300.

Bavestrello G., Bertone S., Cattaneo-Vietti R., Cerrano C., Gaino E., Zanzi D. 1994. Mass mortality of Paramuricea clavata (Anthozoa, Cnidaria) on Portofino Promontory cliffs, Ligurian Sea, Mediterranean Sea. Mar. Life. 4 (1): 15-19.

Bavestrello G., Cerrano C., Zanzi D., Cattaneo-Vietti R. 1997. Damage by fishing activities to the gorgonian coral Paramuricea clavata in the Ligurian Sea. Aquat. Conserv.Mar. Freshw. Ecosyst. 7: 253-262.

Bertolino M., Cerrano C.,Bavestrello G., Carella M., Pansini M., Calcinai B. 2013. Diversity of Porifera in the Mediterranean coralligenous accretions, with description of a new species. Zookeys 336: 1-37.

Bianchi C. N., Cocito S., Morgigni M., Morri C., Peirano A., Sgorbini S. 1994. Benthos del Golfo Tigullio. Fondi duri e prati di Cymodocea. ENEA CRAM, Rapp. Tec. 119 pp.

Bianchi C. N., Morri C., Ugolini U., Sara G., Federghini F. 2002. Studi sull'ambiente marino ai fini della stesura del piano del Parco di Portovenere. Rapp. Tec. 42 pp.

Bianchi C. N., Morri C., Parravicini V., Rovere A. 2006. Realizzazione di cartografia tematica sull'ambiente marino costiero di Bergeggi ed elaborazione di un piano di monitoraggio. Rapp. Tec. 244 pp.

Bianchi C. N., Montefalcone M., Morri C., Parravicini V. 2010. Revisione della distribuzione di specie termofile nel Mar Ligure nell'ultimo ventennio e analisi di dati climatici, relazione intermedia del secondo anno. Accordo programmatico per attività di ricerca internazionale nell'ambito della cooperazione Italia-Israele su ambiente, ricerca e sviluppo. Rapp. Tec. 90 pp.

Cattaneo-Vietti R. 2004. Progetto di studio per la valutazione e valorizzazione delle emergenze naturalistiche dell'Area Naturale Marina Protetta del Promontorio di Portofino. Rapp. Tec.. $36 \mathrm{pp}$.

Cerrano C., Bavestrello G., Bianchi C. N., Cattaneo-Vietti R., Bava S., Morganti C., Morri C., Picco P., Sarà G., Schiaparelli S., Siccardi A., Sponga F. 2000. A catastrophic mass-mortality episode of gorgonians and other organisms in the Ligurian Sea (North-western Mediterranean), summer 1999. Ecol. Lett. 3: 284-293.

Cerrano C., Bavestrello G., Bianchi C. N., Calcinai B., Cattaneo-Vietti R., Morri C., Sara M. 2001. The Role of Sponge Bioerosion in Mediterranean Coralligenous Accretion. In: Faranda F.M., Guglielmo L., Spezie G. (eds), Mediterranean Ecosystems: Structures and Processes. Springer-Verlag, Milano, pp. 235-240.

Cerrano C., Arillo A., Azzini F., Calcinai B., Castellano L., Muti C., Valisano L., Zega G., Bavestrello G. 2005. Gorgonian population recovery after a mass mortality event. Aquatic Conserv. Mar. Freshw. Ecosyst. 15: 147-157.

Cerrano C., Previati M., Palma M., Scinto A., Pantaleo B. 2009 La salvaguardia della biodiversità nei fondalli dell' area marina prospicente il territorio del comune di Santo Stefano al Mare. Rapp. Tec. 25 pp.

Cocito S., Sgorbini S., Bianchi C. N. 1997. Zonation of a suspension-feeder assemblage on a temperate rocky shoal: the influence of water current and bottom topography. Proceedings of the 30 $30^{\text {th }}$ EMBS, Southamptom UK, September 1995.

Cocito S., Sgorbini S., Bianchi C. N. 1998 Aspects of the biology of the bryozoan Pentapora fascialis in the northwestern Mediterranean. Mar. Biol. 131: 73-82.

Cocito S., Bedulli D., Sgorbini S. 2002. Distribution patterns of the sublittoral epibenthic assemblages on a rocky shoal in the Ligurian Sea (NW Mediterranean). Sci. Mar. 66(2): 175-181.

Cupido R., Cocito S., Manno V., Ferrando S., Peirano A., Iannelli L., Bramanti L., Santangelo G. 2012. Sexual structure of a highly reproductive, recovering gorgonian population: quantifying reproductive output. Mar. Ecol. Prog. Ser. 469: 25-36.

ENEA 2012. Prime valutazioni sullo stato dei popolamenti di Posidonia oceanica e coralligeno della baia di Monterosso al Mare a seguito dell'alluvione del 25 ottobre 2011. Rapp. Tec. 4 pp.

Fusco N. 1967. Il Fondo del Mare da Sestri Levante alla foce dell'Arno. Ministero della Marina Mercantile, Direzzione Generale della Pesca Marittima, $165 \mathrm{pp}$. 
Fusco N. 1968. Il Fondo del Mare da Capo di Noli a Sestri Levante. Ministero della Marina Mercantile, Direzzione Generale della Pesca Marittima, $190 \mathrm{pp}$.

Fusco N. 1972. Il Fondo del Mare dal Confine francese a Capo di Noli. Ministero della Marina Mercantile, Direzzione Generale della Pesca Marittima, $175 \mathrm{pp}$

Galliadi A., Lugaresi S., Smadja H. 2003. Immergersi a Portofino, guida alle più belle immersioni dell'area marina protetta. Busco Editrice, Rapallo, $143 \mathrm{pp}$.

Gatti G., Montefalcone M., Rovere A., Parravicini A., Morri C., Albertelli G., Bianchi C.N. 2012. Seafloor integrity down the harbor waterfront: the coralligenous shoals off Vado Ligure (NW Mediterranean). Adv. Oceanogr. Limno. 3 (1): $51-67$.

Leali-Rizzi T., Penco A. 2000. Le armìe di Portofino, guida al parco marino sull'acqua e sott'acqua. Edizioni Le Mani, Recco, 126 pp.

Leali-Rizzi T., Penco A. 2001. Liguria in Blu, guida alle immersioni subacquee da Ventimiglia a La Spezia. Edizione Le Mani, Recco, 174 pp.

Massajoli M., Barsotti G. 2003. Logbook Portofino, guida alle immersioni dell'Area Marina Naturale Protetta. Auriga Publishing International, Genova, $31 \mathrm{pp}$.

Melegari G. 1973. Portofino sub, guida alla conoscenza dei fondali del promontorio di portofino. Erga Genova, 198 pp.

Montefalcone M., Bianchi C. N., Morri C., Albertelli G. 2010. Monitoraggio delle secche coralligene nell'Area di Vado Ligure (SV). Rapp. Tec.. 90 pp.

Morri C. 2000. Consulenza riguardante il comparto ambientale "flora e fauna" e verifica impianto depurazione di Levanto e Bonassola: ambiente marino. Rapp. Tec. 21 pp.

Morri C., Bianchi C. N., Damiani V., Peirano A., Romeo G., Tunesi L. 1986. L'ambiente marino tra Punta della Chiappa e Sestri Levante (Mar Ligure): profilo ecotipologico e proposta di carta bionomica. Boll. Mus. Ist. Biol. Univ. Genova 52: $213-231$.

Pansini M., Pessani D., Pronzato R. 1976. Relazione sui campioni raccolti ed elenco delle specie determinate. Parma-Sub. Rapp. Tec. 29 pp.

Parravicini V., Donato M., Rovere A., Montefalcone M., Albertelli G., Bianchi C. N. 2007. Indagine preliminare sul coralligeno dell'area di Bergeggi (SV): tipologie ed ipotesi sul suo mantenimento. Biol. Mar. Medit. 14 (2): 162-163.

Peirano A., Tunesi L., 1989. Modificazioni nella composizione del popolamento ad Antozoi del coralligeno di Punta Mesco (Mar Ligure di Levante) a 30 anni dalle prime osservazioni. Nova Thalassia, 10: 543-548.

Peirano A., Sassarini M. 1992. Analisi delle caratteristiche distributive di alcune facies di substrato duro dei fondali delle cinque terre (Mar Ligure). Oebalia 17: 523-528.

Peirano A., Salvati E., Bianchi C. N., Morri C. 2000. Long-term change in the subtidal epibenthic assemblages of Punta Mesco (Ligurian Sea, Italy) as assessed through underwater photography. PMNHS Newsletter 5: 9-12.

Previati M., Palma M., Scinto A. 2007. Description of coralligenous communities of Imperia. Biol. Mar. Medit. 14 (2):164-165.

Previati M., Scinto A., Enrico G., Palma M., Cerrano C. 2009. Emergenze naturalistiche dei fondali dell'imperiese. Boll. Mus. Ist. Biol. Univ. Genova, 71: 185 .

Previati M. 2011. Ponente nel Blu, il SIC di Capo Berta. Comune di Imperia, Italia. Edizioni Amadeo, Imperia, 141 pp.

Previati M., Enrico G., Palma M. 2011. Il coralligeno del Ponente Ligure:dati preliminari sul coralligeno mesofotico preso il SIC di Capo Berta. Biol. Mar. Medit. 18 (1):284-285.

Previati M., Enrico G. 2012. Richiesta di ampliamento dei limiti di tutela nel Sito di Importanza Comunitaria di Capo Berta (Imperia). Centro di Educazione Ambientale del Comune di Imperia. Rapp. Tec. 15 pp.

Relini M., Torchia G., Cima C., Palandri G. 1999. Studio ambientale sulla fascia costiera di Arenzano. Idra. Rapp. Tec. 53 pp.

Rossi L. 1961. Sur un facies a gorgonaires de la Pointe du Mesco (Golfe de Gênes). Rapp P V Comm Int Explor Sci Mer Médit. 16(2): 517-521.

Rossi L. 1965a. Influenza dei fattori ambientali sulla facies a Gorgonacei di Punta Mesco (Riviera Levante). Boll. Zool. 32(2): 859-865.

Rossi L. 1965b. Il coralligeno di Punta Mesco (La Spezia). Ann. Mus. Civ. Stor. Nat. Genova. 75: $144-180$.

Rovere A., Parravicini V. 2006. Indagine geomorfologica e bionomica degli affioramenti coralligeni profondi antistanti le falesie di Punta Manara (Ge). Rapp. Tec. 41 pp.

Rovere A., Parravicini V., Donato M., Riva C., Diviacco G., Coppo S., Firpo M., Bianchi C. N. 2006. Indagini sulle secche di Punta Manara: un esempio di approccio ecotipologico. Biol. Mar. Medit. 13(2):210-211.

Salvati E. 1997. Studio del coralligeno di Punta Mesco (Mar Ligure orientale) tramite analisi di immagine e confronto con dati storici. Master thesis, Univ. Roma, 112 pp.

Santi G.1965. Il pescatore dilettante con ami in acque marine. Hoepli, $444 \mathrm{pp}$

Sara G. 2003. Indicatori ecologici e criteri di valutazione ambientale nel parco marino di Porto Venere. Master thesis, Univ. Pisa, 65 pp.

Sara G., Gasparini G. P., Morri C., Bianchi C. N., Cinelli F. 2003. Reclutamento di Gorgonie dopo un episodio di moria di massa in Mar Ligure Orientale. Biol. Mar. Medit. 10(2): 176-182.

Scinto A, Bertolino M, Calcinai B, Huete-Stauffer C, Previati M, Romagnoli T, CerranoC. 2009. Role of a Paramuricea clavata forest in modifying the coralligenous assemblages. Proceedings of the 1st Mediterranean symposium on the conservation of the coralligenous and other calcareous bio-concretions. RAC/SPA Publ. Tunis, pp: 137-141.

Tommei A. 1993. Il promontorio di Portofino, le guide subacquee. Edizione La Cuba, Roma, 142 pp.

Tortonese E., Faraggiana R. 1937. Osservazioni biologiche nell'insenatura di levanto. Estratto dalla Rivista di Scienze Naturali. 28 : 50-72.

Tortonese E. 1958. Bionomia marina della regione costiera fra Punta della Chiappa e Portofino (Riviera Ligure di Levante). Arch. Oceanogr. Limnol. 12(2): 167-210.

Tortonese E. 1961. Nuovo contributo alla conoscenza del bentos della scogliera ligure. Arch. Oceanogr. Limnol. 12(2): $163-183$.

Vota P. 2008. La futura area di tutela marina regionale di Capo Mortola: stato delle conoscenze. Master thesis, Univ. Genova, 232 pp. 
Table S2. - Ligurian localities with coralligenous and main characteristics. N/A, No data available. * Facies not included in the EUNIS Habitat 2004 classification for Mediterranean coralligenous communities.

\begin{tabular}{|c|c|c|c|c|c|c|}
\hline Locality & Site & Depth (m) & Geomorphotype & Facies & Pressures & $\mathrm{Ha}$ \\
\hline \multirow[t]{7}{*}{ Capo Mortola } & Canyon (Pertuso) & $18-35$ & paleocliff & Paramuricea clavata & Caulerpa cylindracea & 0.46 \\
\hline & Desolation & $20-33$ & paleocliff & Paramuricea clavata & N/A & 0.31 \\
\hline & San Giuseppe & $15-25$ & paleocliff & Eunicella cavolini & Caulerpa cylindracea & 0.71 \\
\hline & Monaco & 14-39 & paleocliff & Paramuricea clavata & N/A & 2.02 \\
\hline & Pignatum & $35-43$ & paleocliff & Paramuricea clavata & N/A & 0.20 \\
\hline & Aragostine & $28-35$ & shoals & Paramuricea clavata & N/A & 0.19 \\
\hline & Fontana & $24-36$ & shoals & Paramuricea clavata & N/A & 0.62 \\
\hline Santo Stefano & Santo Stefano & $25-40$ & shoals & Paramuricea clavata & Fishing gears & 21.81 \\
\hline \multirow{3}{*}{ Porto Maurizio } & Gorgonie & $34-40$ & shoals & Paramuricea clavata & Fishing gears, anchors & 0.38 \\
\hline & Nebbia & $49-54$ & shoals & Paramuricea clavata & N/A & 0.29 \\
\hline & Maldive & $50-56$ & shoals & Paramuricea clavata & N/A & 0.20 \\
\hline \multirow[t]{7}{*}{ Capo Berta } & Scogli dell' Ariete & $50-56$ & shoals & Massive/erect sponges* & N/A & 0.29 \\
\hline & Diano 40 & $38-44$ & shoals & Eunicella spp. & N/A & 0.13 \\
\hline & Diano 56 & $54-56$ & shoals & Eunicella singularis & N/A & 0.16 \\
\hline & Carri armati & $52-60$ & shoals & Paramuricea clavata & N/A & 0.28 \\
\hline & Il muraglione & $30-35$ & shoals & Mesophyllum lichenoides & Caulerpa cylindracea & 0.29 \\
\hline & Il Pilone & $32-37$ & shoals & Eunicella verrucosa* & N/A & 0.23 \\
\hline & Le Stelle & $34-38$ & shoals & Massive/erect sponges* & N/A & 0.28 \\
\hline \multirow[t]{2}{*}{ Capo Mele } & Il Giardino & $29-36$ & shoals & Eunicella spp. & N/A & 3.73 \\
\hline & Scoglio di Capo Mele & $34-40$ & shoals & Paramuricea clavata & N/A & 3.43 \\
\hline \multirow[t]{2}{*}{ Isola Gallinara } & Punta Falconara & $25-45$ & plunging cliff & $\begin{array}{l}\text { Massive/erect sponges* } \\
\text { Leptogorgia sarmentosa }\end{array}$ & Anchors, mass mortality & 2.34 \\
\hline & Punta Sciusciaü & $25-45$ & plunging cliff & $\begin{array}{l}\text { Massive/erect sponges*, } \\
\text { Leptogorgia sarmentosa }\end{array}$ & Anchors, mass mortality & 1.37 \\
\hline \multirow{4}{*}{$\begin{array}{l}\text { Isola di } \\
\text { Bergeggi }\end{array}$} & Secca dei maledetti & $50-113$ & paleocliff & Paramuricea clavata & N/A & 20.21 \\
\hline & Secca della travacca & $50-78$ & paleocliff & Paramuricea clavata & N/A & 4.24 \\
\hline & Secca del banano & $60-80$ & shoals & Paramuricea clavata & N/A & 3.26 \\
\hline & Scoglietti di Bergeggi & $26-35$ & shoals & Massive/erect sponges* & N/A & 0.64 \\
\hline \multirow[t]{6}{*}{ Vado Ligure } & Corallo nero & $30-36$ & shoals & Paramuricea clavata & N/A & 0.05 \\
\hline & $\mathrm{C} 3$ & $31-38$ & shoals & Paramuricea clavata & Fishing gears, plastic bags & 0.01 \\
\hline & $\mathrm{C} 2$ & $20-28$ & shoals & Parazoanthus axinellae & Fishing gears & 0.03 \\
\hline & $\mathrm{C} 4$ & $21-23$ & shoals & Cystoseira zosteroides & Fishing gears & 0.02 \\
\hline & C5 & $17-18$ & shoals & Leptogorgia sarmentosa & Anchors & 0.01 \\
\hline & $\mathrm{C} 1$ & $22-30$ & shoals & Parazoanthus axinellae & N/A & 0.03 \\
\hline \multirow[t]{3}{*}{ Varazze } & Secca dei Cerianthus & $29-36$ & shoals & N/A & N/A & 0.36 \\
\hline & Secca a Varazze & $45-46$ & shoals & Eunicella verrucosa* & N/A & 0.50 \\
\hline & Secca dei Forzieri & $32-33$ & shoals & Massive/erect sponges* & N/A & 0.63 \\
\hline \multirow[t]{2}{*}{ Cogoleto } & Punto41,42 & $29-38$ & shoals & N/A & N/A & 0.24 \\
\hline & $\begin{array}{l}\text { Secche San } \\
\text { Giaccomo }\end{array}$ & $28-35$ & shoals & Paramuricea clavata & Fishing gears & 0.16 \\
\hline \multirow[t]{4}{*}{ Arenzano } & Secca 2 balconi & $43-48$ & shoals & Paramuricea clavata & N/A & 0.12 \\
\hline & Secche ad Arenzano & $30-33$ & shoals & Massive/erect sponges* & Fishing gears & 0.11 \\
\hline & $\begin{array}{l}\text { Punta Martino - } \\
\text { Marina Grande }\end{array}$ & $38-42$ & shoals & Paramuricea clavata & N/A & 0.23 \\
\hline & $\begin{array}{l}\text { Punta Martino - } \\
\text { Marina Grande }\end{array}$ & $30-32$ & shoals & Massive/erect sponges* & N/A & 0.68 \\
\hline \multirow[t]{17}{*}{ Portofino } & Punta Chiappa & $33-50$ & plunging cliff & $\begin{array}{l}\text { Paramuricea clavata, } \\
\text { Leptogorgia sarmentosa }\end{array}$ & N/A & 1.74 \\
\hline & Secca dell'Isuela & $15-55$ & shoals & $\begin{array}{c}\text { Cystoseira zosteroides, } \\
\text { Eunicella cavolini, } \\
\text { Paramuricea clavata }\end{array}$ & N/A & 3.55 \\
\hline & Punta Targhetta & $11-40$ & plunging cliff & $\begin{array}{l}\text { Eunicella cavolini } \\
\text { Corallium rubrum* }\end{array}$ & N/A & 2.19 \\
\hline & Punta Bussago & $25-45$ & plunging cliff & Paramuricea clavata & N/A & 3.02 \\
\hline & Cala dell'Oro O & $30-40$ & plunging cliff & Eunicella cavolini & N/A & 1.07 \\
\hline & Cala dell'Oro E & $10-50$ & plunging cliff & $\begin{array}{l}\text { Eunicella cavolini, } \\
\text { Paramuricea clavata }\end{array}$ & N/A & 3.01 \\
\hline & Punta Torretta & $10-48$ & plunging cliff & $\begin{array}{l}\text { Eunicella cavolini, } \\
\text { Paramuricea clavata }\end{array}$ & Mass mortality event & 1.77 \\
\hline & Punta Volpe & $20-40$ & plunging cliff & Paramuricea clavata & N/A & 0.58 \\
\hline & San Fruttuoso & $25-35$ & plunging cliff & Corallium rubrum* & N/A & 0.43 \\
\hline & Cristo degli Abissi & $23-30$ & plunging cliff & Corallium rubrum* & N/A & 0.31 \\
\hline & Scogliera del dragone & $40-60$ & shoals & Paramuricea clavata & N/A & 1.39 \\
\hline & Tetto del Dragone & $18-40$ & plunging cliff & Paramuricea clavata & N/A & 1.21 \\
\hline & Secca Gonzatti & $30-60$ & shoals & Paramuricea clavata & N/A & 0.92 \\
\hline & Punta Carega & $18-40$ & plunging cliff & $\begin{array}{l}\text { Eunicella cavolini } \\
\text { Paramuricea clavata }\end{array}$ & N/A & 0.51 \\
\hline & Scoglio del Raviolo & $23-33$ & rockfalls & Paramuricea clavata & N/A & 0.13 \\
\hline & Testa del Leone & $25-38$ & rockfalls & Paramuricea clavata & N/A & 1.18 \\
\hline & Punta Fregante & $20-42$ & plunging cliff & $\begin{array}{l}\text { Eunicella cavolini } \\
\text { Eunicella singularis }\end{array}$ & N/A & 0.79 \\
\hline
\end{tabular}




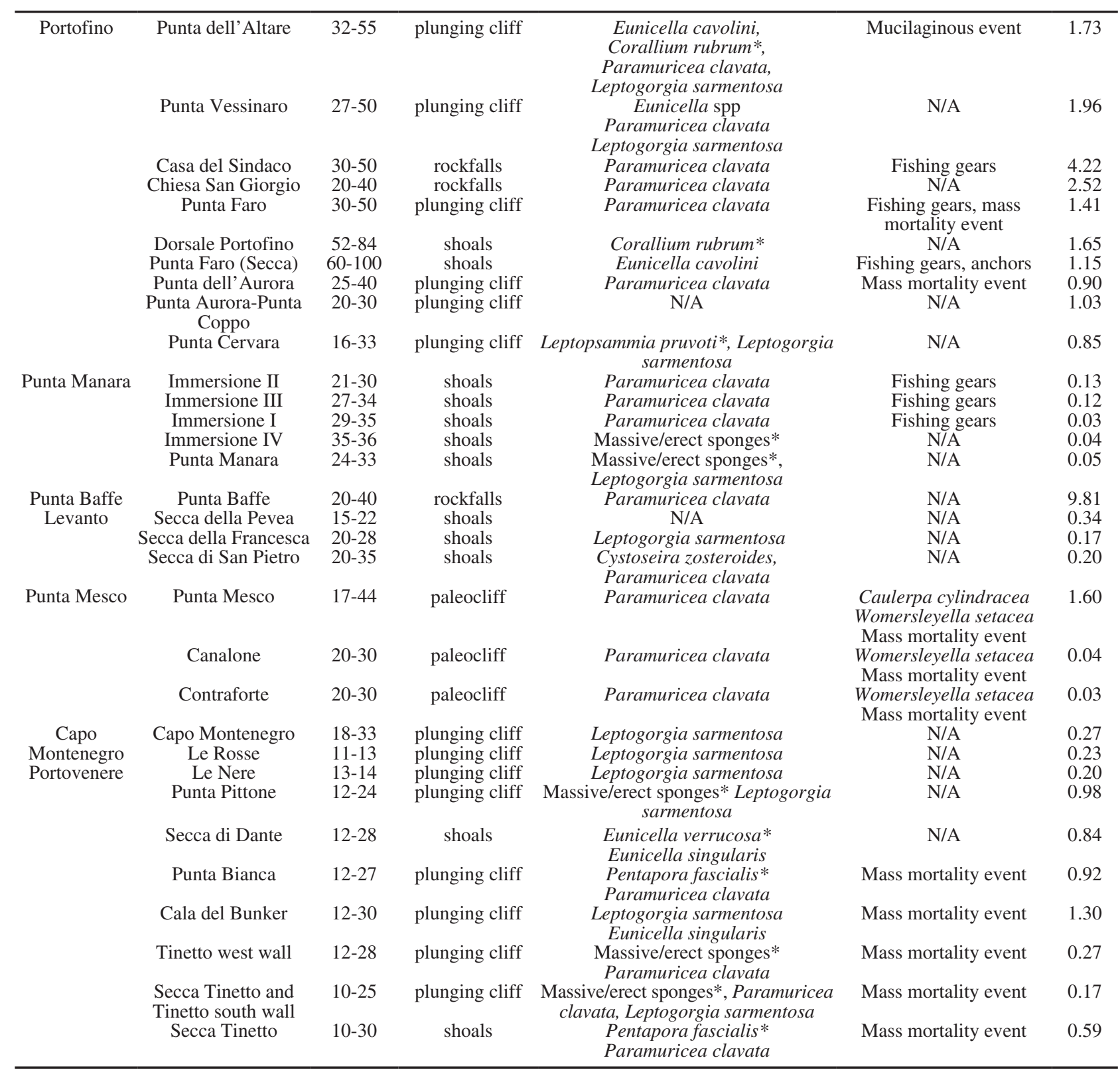


Table S3. - List of sessile megabenthos taxa reported by different authors for the Ligurian coralligenous community.

Taxonomic groups

\section{Foraminifera}

Miniacina miniacea (Palas, 1766)

\section{Algae}

Amphiroa J.V.Lamouroux, 1812

Cladophora prolifera (Roth) Kützing, 1843

Codium bursa (Olivi) C.Agardh, 1817

Codium vermilara (Olivi) Delle Chiaje, 1829

Contarinia squamariae (Meneghini) Denizot, 1968

Cystoseira zosteroides C.Agardh, 1820

Dictyopteris polypodioides (A.P.De Candolle) J.V.Lamouroux, 1809

Dictyota dichotoma (Hudson) J.V.Lamouroux, 1809

Ectocarpus Lyngbye, 1819

Flabellia petiolata (Turra) Nizamuddin, 1987

Halimeda tuna (J.Ellis and Solander) J.V.Lamouroux, 1816

Kallymenia requienii (J.Agardh) J.Agardh, 1842

Lithophyllum incrustans R.A.Philippi, 1837

Lithophyllum (Philippi, 1837)

Lythophyllum stictaeformis (Areschoug) Hauck, 1877

Mesophyllum alternans (Foslie) Cabioch and M.L.Mendoza, 1998

Mesophyllum expansum (Philippi) Cabioch and M.L.Mendoza, 2003

Mesophyllum lichenoides (J.Ellis) Me.Lemoine, 1928

Mesophyllum (Me.Lemoine, 1928)

Neogoniolithon brassica-florida (Harvey) Setchell and L.R.Mason, 1943

Nereia filiformis (J.Agardh) Zanardini, 1846

Osmundaria volubilis (Linnaeus) R.E.Norris, 1991

Padina pavonica (Linnaeus) Thivy, 1960

Palmophyllum crassum (Naccari) Rabenhorst, 1868

Peyssonnelia rubra (Greville) J.Agardh, 1851

Peyssonnelia squamaria (S.G.Gmelin) Decaisne, 1842

Peyssonnelia (Decaisne, 1841)

Phorbas tenacior (Topsent, 1925)

Phyllophora crispa (Hudson) P.S.Dixon, 1964

Rytiphlaea tinctoria (Clemente) C.Agardh, 1824

Sargassum C.Agardh, 1820

Sphaerococcus coronopifolius Stackhouse, 1797

Sporochnus pedunculatus (Hudson) C.Agardh, 1820

Tricleocarpa fragilis (Linnaeus) Huisman and R.A.Townsend, 1993

Zanardinia typus (Nardo) P.C.Silva, 2000

\section{Porifera}

Aaptos aaptos (Schmidt, 1864)

Acanthella acuta (Schmidt, 1862)

Agelas oroides (Schmidt, 1864)

Antho (Antho) involvens (Schmidt, 1864)

Aplysina aerophoba Nardo, 1833

Aplysina cavernicola (Vacelet, 1959)

Axinella cannabina (Esper, 1794)

Axinella damicornis (Esper, 1794)

Axinella polypoides (Schmidt, 1862)

Axinella vaceleti (Pansini, 1984)

Axinella verrucosa (Esper, 1794)

Borojevia cerebrum (Haeckel, 1872)

Bubaris carcisis Vacelet, 1969

Bubaris vermiculata (Bowerbank, 1866)

Calyx nicaeensis (Risso, 1826)

Chondrilla nucula Schmidt, 1862

Chondrosia reniformis (Nardo, 1847)

Clathria (Microciona) armata (Bowerbank, 1866)

Clathria (Microciona) atrasanguinea (Bowerbank, 1862)

Clathria (Microciona) gradalis Topsent, 1925

Clathria (Microciona) haplotoxa (Topsent, 1928)

Clathria (Microciona) toxistyla (Sarà, 1959)

Clathria (Microciona) toxivaria (Sarà, 1959)

Clathrina (Gray, 1867)

Clathrina clathrus (Schmidt, 1864)

Cliona celata Grant, 1826

Cliona janitrix Topsent, 1932

Cliona schmidtii (Ridley, 1881)

Cliona viridis (Schmidt, 1862)

Crambe crambe (Schmidt, 1862)

Crella (Crella) elegans (Schmidt, 1862)

Crella (Crella) mollior Topsent, 1925

Crella (Grayella) pulvinar (Schmidt, 1868)

Delectona de Laubenfels, 1936

Dendroxea lenis (Topsent, 1892)
Hymerhabdia typica Topsent, 1892

Ircinia (Nardo, 1833)

Ircinia selaginea (Lamarck, 1814)

Ircinia variabilis (Schmidt, 1862)

Jaspis johnstonii (Schmidt, 1862)

Leucosolenia variabilis (Haeckel, 1870)

Lissodendoryx (Lissodendoryx) isodictyalis (Carter, 1882)

Mycale (Aegogropila) tunicata (Schmidt, 1862)

Oscarella lobularis (Schmidt, 1862)

Penares euastrum (Schmidt, 1868)

Petrosia (Petrosia) clavata (Esper, 1794)

Petrosia (Petrosia) ficiformis (Poiret, 1789)

Phakellia Bowerbank, 1862

Phorbas fictitius Bowerbank, 1866

Phorbas mercator (Schmidt, 1868)

Phorbas tenacior (Topsent, 1925)

Plakortis simplex Schulze, 1880

Pleraplysilla minchini Topsent, 1905

Pleraplysilla spinifera (Schulze, 1879)

Plocamionida ambigua (Bowerbank, 1866)

Poecillastra compressa (Bowerbank, 1866)

Polymastia Bowerbank, 1864

Pseudosuberites sulphureus (Bowerbank, 1866)

Raspaciona aculeata (Johnston, 1842)

Sarcotragus fasciculatus (Pallas, 1766)

Sarcotragus foetidus Schmidt, 1862

Sarcotragus spinosulus (Schmidt, 1862)

Scalarispongia scalaris (Schmidt, 1862)

Siphonodictyon insidiosum (Johnson, 1899)

Spirastrella cunctatrix Schmidt, 1868

Spiroxya heteroclita Topsent, 1896

Spongia (Spongia) lamella (Schulze, 1879)

Spongia (Spongia) officinalis Linnaeus, 1759

Spongia (Spongia) virgultosa (Schmidt, 1868)

Spongia Linnaeus, 1759

Suberites carnosus (Johnston, 1842)

Suberites domuncula (Olivi, 1792)

Tedania (Tedania) anhelans (Lieberkühn, 1859)

Terpios gelatinosa (Bowerbank, 1866)

Timea stellata (Bowerbank, 1866)

Timea unistellata (Topsent, 1892)

Triptolemma simplex (Sarà, 1959)

\section{Cnidaria}

Actinia cari Delle Chiaje, 1822

Aglaophenia pluma (Linnaeus, 1758)

Aiptasia mutabilis (Gravenhorst, 1831)

Alcyonium acaule Marion, 1878

Alcyonium coralloides (Pallas, 1766)

Alcyonium palmatum Pallas, 1766

Alicia mirabilis Johnson, 1861

Balanophyllia (Balanophyllia) europaea (Risso, 1826)

Caryophyllia (Caryophyllia) smithii Stokes and Broderip, 1828

Cerianthus membranaceus (Spallanzani, 1784)

Cladocora caespitosa (Linnaeus, 1767)

Corallium rubrum (Linnaeus, 1758)

Eudendrium racemosum (Cavolini, 1785)

Eunicella cavolini (Koch, 1887)

Eunicella singularis (Esper, 1791)

Eunicella verrucosa (Pallas, 1766)

Eunicella Verrill, 1869

Leptogorgia sarmentosa (Esper, 1789)

Leptopsammia pruvoti (Lacaze-Duthiers, 1897)

Lytocarpia myriophyllum (Linnaeus, 1758)

Madracis pharensis (Heller, 1868)

Obelia dichotoma (Linnaeus, 1758)

Paramuricea clavata (Risso, 1826)

Paramuricea macrospina (Koch, 1882)

Parazoanthus axinellae (Schmidt, 1862)

Pennaria disticha (Goldfuss, 1820)

Pennaria Goldfuss, 1820

Pennatula rubra (Ellis, 1761)

Phyllangia americana mouchezii (Lacaze-Duthiers, 1897)

Polycyathus muellerae (Abel, 1959)

Savalia savaglia (Bertoloni, 1819) 
Dercitus (Stoeba) plicatus (Schmidt, 1868)

Dictyonella incisa (Schmidt, 1880)

Dictyonella marsilii (Topsent, 1893)

Dictyonella obtusa (Schmidt, 1862)

Dictyonella pelligera (Schmidt, 1862)

Diplastrella bistellata (Schmidt, 1862)

Dysidea (Johnston, 1842)

Dysidea avara (Schmidt, 1862)

Dysidea fragilis (Montagu, 1814)

Erylus discophorus (Schmidt, 1862)

Eurypon cinctum Sarà, 1960

Eurypon clavatum (Bowerbank, 1866)

Eurypon coronula (Bowerbank, 1874)

Eurypon denisae Vacelet, 1969

Eurypon gracile Bertolino, Calcinai and Pansini, 2013

Eurypon major Sarà and Siribelli, 1960

Eurypon topsenti Pulitzer-Finali, 1983

Eurypon vesciculare Sarà and Siribelli, 1960

Forcepia (Leptolabis) brunnea (Topsent, 1904)

Geodia conchilega Schmidt, 1862

Geodia cydonium (Jameson, 1811)

Halichondria (Halichondria) convolvens Sarà, 1960

Haliclona (Gellius) angulata (Bowerbank, 1866)

Haliclona (Gellius) marismedi (Pulitzer-Finali, 1978)

Haliclona (Halichoclona) fulva (Topsent, 1893)

Haliclona (Halichoclona) parietalis (Topsent, 1893)

Haliclona (Reniera) citrina (Topsent, 1892)

Haliclona (Reniera) cratera (Schmidt, 1862)

Haliclona (Reniera) mediterranea (Griessinger, 1971)

Haliclona (Rhizoniera) rosea (Bowerbank, 1866)

Haliclona (Soestella) mucosa (Griessinger, 1971)

Halicnemia geniculata Sarà, 1958

Halicnemia patera Bowerbank, 1864

Halisarca dujardinii (Johnston, 1842)

Hemimycale columella (Bowerbank, 1874)

Hippospongia communis (Lamarck, 1814)

Hymedesmia (Stylopus) coriacea (Fristedt, 1866)

Hymerhabdia oxytrunca Topsent, 1904
Polychaeta

Filograna (Berkeley, 1835)

Protula tubularia (Montagu, 1803)

Sabella spallanzanii (Gmelin, 1791)

Salmacina dysteri (Huxley, 1855)

Serpula vermicularis Linnaeus, 1767

Serpulidae Rafinesque, 1815

Bivalvia

Pinna nobilis Linnaeus, 1758

Bryozoa

Cellaria fistulosa (Linnaeus, 1758)

Cradoscrupocellaria reptans (Linnaeus, 1758)

Myriapora truncata (Pallas, 1766)

Pentapora fascialis (Pallas, 1766)

Pentapora foliacea (Ellis and Solander, 1786)

Reteporella beaniana (King, 1846)

Reteporella grimaldii (Jullien, 1903)

Reteporella (Busk, 1884)

Rhynchozoon Hincks, 1895

Schizomavella linearis (Hassall, 1841)

Schizoporella errata (Waters, 1878)

Schizoporella (Hincks, 1877)

Scrupocellaria scrupea Busk, 1852

Smittina cervicornis (Pallas, 1766)

Turbicellepora avicularis (Hincks, 1860)

\section{Ascidiacea}

Aplidium conicum (Olivi, 1792)

Ciona edwardsi (Roule, 1884)

Clavelina lepadiformis (Müller, 1776)

Diplosoma spongiforme (Giard, 1872)

Halocynthia papillosa (Linnaeus, 1767)

Microcosmus vulgaris Heller, 1877

Phallusia fumigata (Grube, 1864) 